\title{
BENTUK DAKWAH DI TWITTER MENJELANG PILKADA DKI JAKARTA TAHUN 2017
}

\author{
Taufik Syam \\ Kamaluddin Tajibu \\ Usman Jasad \\ Nurhidayat M. Said \\ Institut Agama Islam Negeri Parepare \\ taufiqsyam008@gmail.com
}

\begin{abstract}
Abstrak: Mencoba melakukan studi kasus terhadap perang dakwah yang terjadi di media sosial, dalam hal ini yang terdapat di Twitter berdasarkan atas wacana, opini, berita-berita di situs online, video dan komentar dari beberapa akun yang terlibat dari perang dakwah ini yang terjadi sebelum pemilihan gubernur di Pilkada DKI Jakarta tahun 2017.

Jenis penelitian ini adalah penelitian kualitatif atau naturalistik. Pendekatan penelitian ini adalah pendekatan sosioligi komunikasi dalam bentuk studi kasus (case study) terhadap arena produksi kultural merujuk pada konsep, pendapat, pemikiran, dan komentar para dại maupun masyarakat dalam bentuk tulisan, berita/ wacana, pesan gambar, status personal, komentar terhadap status seseorang dan video ceramah dan debat dakwah yang diunggah ke media sosial yang nantinya akan menggiring opini publik ke dalam ranah pembentukan mindset kecenderungan (disposisi) terhadap suatu otoritas (authority) yang sedang terjadi. Lokasi penelitian ini adalah media sosial terkhusus pada media sosial yang sering digunakan yaitu Tweeter. Sumber data pada penelitian dari informan yang digunakan dalam penelitian ini yaitu para pengguna media sosial Facebook. Teknik pengumpulan data adalah observari, dokumentasi. Instrumen penelitian adalah pedoman observasi dan alat dokumentasi. Proses pengujian keabsahan data terdiri kredibilitas, transferbilatas, depenbilitas dan konfimabilitas. Teknik pengolahan dan analisis data terdiri dari reduksi data, display data, dan verifikasi atau penarikan kesimpulan.

Berdasarkan pada data penelitian, terdapat beberapa status dari para dai atau pun public figure yang dijadikan sebagai objek penelitian. Jumlah status dakwah di media sosial yang dijadikan sebagai data penelitian yaitu data yang bersumber dari Twitter sebanyak 54. Hasil penelitian ini menunjukkan bahwa bentuk dakwah di media sosial pada masa Pilkada DKI Jakarta tahun 2017 tidak terlepas dari bentuk dakwah secara umum yaitu da'wah bi al-lisan, da'wah bi al-qalam, dan da'wah bi al-hal, yang teritegrasikan dengan bentuk dakwah siyasah yang terdiri dari siyasah khajiriyah, siyasah dakhiliyah dan siyasah tarbawiyah.
\end{abstract}

\section{Keywords: Tweeter; Da'wah bi al-Lisan; Da'wah bi al-Qalam}

\section{PENDAHULUAN}

Hari ini, apapun bentuknya, aktivitas dakwah mutlak menggunakan media (channel) dakwah. Perkembangan dan kemajuan teknologi media massa khususnya radio, televisi dan internet dapat dimanfaatkan sebagai media dakwah. 
Pada dasarnya media dakwah yang digunakan mengacu pada siapa objek dakwah yang dihadapi, kepandaian subjek dakwah menggunakan media dakwah dapat mempengaruhi berhasil tidaknya pelaksanaan dakwah Islamiyah. Sebaliknya, keahlian subjek dakwah meramu materi dakwah dengan kesesuaian media yang digunakan, dapat menjadi faktor penunjang keberhasilan dakwah. Perlu diingat adalah, materi dakwah adakalanya memerlukan media tertentu dalam pelaksanaanya. ${ }^{1}$ Oleh karena itu, pemahaman terhadap penggunaan teknologi juga menjadi hal yang penting untuk dikuasai seorang dai dalam berdakwah.

Secara esensial, terdapat dua pandangan dalam hubungan antara teknologi dan masyarakat. Pertama, teknologi menentukan budaya masyarakat. Pandangan ini memfokuskan pada efek sosial. Di dalam pandangan ini terdapat tiga pokok pikiran yaitu medium is the message (media adalah pesan), technology as dominant social force (teknologi sebagai penjuang sosial yang dominan) dan media drive culture (media mengendalikan kebudayaan). ${ }^{2}$ Oleh karena itu teknologi tidak dapat dipisahkan dari pembicaraan, ideologi, organisasi, teknik alat dan berbagai aspek unsur budaya yang berkembang di tengah masyarakat, termasuk dalam ruang lingkup dakwah di media massa.

Pada akhir abad ke 20, teknologi komunikasi memasuki era baru, yang dikenal dengan era komunikasi digital. Pada era ini terjadi sebuah proses elaborasi antara media cetak dan media elektronik, media ini kemudian dikenal dengan istilah media komunikasi internet atau cyberspace. Cikal bakal lahirnya media internet dimulai pada saat ditemukannya sebuah perangkat komputer bernama ENIAC sebagai sebuah alat yang dapat mengkonversi beberapa peralatan penting yang sering di gunakan oleh manusia dalam kehidupan sehari-sehari ${ }^{3}$.

Keberadaan internet yang awalnya hanya untuk mengajak setiap orang saling berinterkasi satu sama lain dengan lebih komunikatif, karena komunikasi yang terbangun adalah komunikasi dua arah yaitu antara pengirim pesan atau sender dan penerima pesan atau receiver, yang diperantarai oleh internet sebagai medianya, berubah menjadi semakin modern dan inovatif. Setiap orang digiring untuk membentuk sebuah kebutuhan baru terhadap dunia internet. Eksistensi keberadaan internet ini semakin meluas, dengan dibuatnya beberapa layanan dalam bentuk situs jejaring yang memungkinkan setiap orang saling berinterkasi satu sama lain dalam rentan waktu yang relatif cepat, dengan hanya menggunakan alat elektonik seperti computer, laptop dan handphone, tanpa harus bertemu dan bertatap muka secara lansung. Layanan situs jejaring inilah yang akhirnya dikenal dengan nama media sosial.

\footnotetext{
${ }^{1}$ Japaruddin, Media Massa dan Dakwah (Jurnal Dakwah Vol. XIII, No. 1; STAIN Bengkulu. 2012), h. 2

${ }^{2}$ Arnold Pacey, The Culture of Technology, Ninth Printing dalam Amar Ahmad, Dinamika Media Islami di Media Online (Jurnal Ilmu Komunikasi Vol. 11 No. 1; UIN Alauddin Makassar, 2013), h. 45

${ }^{3}$ Rogers Everette, A History of Communication Study, dalam Rulli Nasrullah, Komunikasi AntarBudaya: Di Era Budaya Siber (Cet.2; Jakarta: Pranemdia Group. 2014), h. 4
} 
Sebagaimana yang telah diketahui bersama, bahwa media sosial yang merupakan representasi dari perkembangan media online, dimana para penggunanya dapat mencari informasi, berkomunikasi dan menjaring pertemanan dengan segala fasilitas pendukung yang telajh disiapkan di dalamnya. Media sosial seperti Facebook, Twitter, YouTube dan Blog telah membawa pengaruh tersendiri terhadap masyarakat saat ini. ${ }^{4}$ Hal ini tentu saja memberikan peluang yang besar terhadap terciptanya proses komunikasi yang berlansung secara efektif di masyarakat era post industrial.

Kegiatan dakwah yang dilakukan di media sosial dilakukan dengan berbagai cara. Pada media sosial Twitter, informasi dakwah yang dilakukan umumnya lebih banyak memuat personal status (status pribadi) dalam bentuk quotes (kutipan-kutipan) kata-kata nasihat dari seorang ulama atau dai.

Salah satu hal yang paling menarik yaitu terjadi perang dakwah antara ulama yang mendukung setiap kandidat. Perdebatan bukan antara kelompok mayoritas Islam dengan kelompok minoritas agama lain, akan tetapi pro dan kontra lahir dari tokoh-tokoh agama Islam sendiri dalam meperdebatkan siapa gubernur yang ideal yang nantinya akan dipilih dalam Pilkada DKI Jakarta tahun 2017.

Penghasutan wacana yang begitu membahana dalam Pilkada DKI Jakarta tahun 2017, mulai dari tuduhan penistaan agama, liberalisasi agama, kampanye anti syariat Islam, sekularisasi hingga pengaburan sejarah mulai menjadi makanan sehari-hari umat Islam. Puncaknya ketika terjadi demonstrasi berlabelkan "Aksi Bela Islam” yang dipimpin oleh tokoh-tokoh Islam, seperti Habib Rizieq Syihab, Bachtiar Natsir, K.H Abdullah Gynamstiar, Ust. Arifin Ilahm, dan tokoh Islam lainnya menuntut kepada pihak yang berwajib untuk memenjarakan salah satu calon gubernur DKI Jakarta yang juga sedang menjabat sebagai gubernur dengan tuduhan penistaan agama. Di lain sisi, beberapa tokoh Islam seperti Buya Safi'i Maarif, Quraish Syihab, Ust. Mustafa Bisri, dan tokoh lainnya menyayangkan aksi tersebut dan mengingatkan untuk tidak terlibat dalam aksi tersebut untuk menghidari keretakan ke-bhineka-an Indonesia.

Perang perdebatan yang dikemas dalam dakwah tersebut terjadi di media sosial dangan cara saling melemparkan wacana,opini, fatwa, video dakwah dan komentar-komentar dari setiap akun yang ada di media sosial. Sehingga secara sadar maupun tidak sadar, setiap orang yang terlibat dalam perang ini menjadi agen-agen dari ideologi masing-masing dan berdampak pada terbentuknya sebuah arena produksi kultural yang secara lansung maupun tidak lansung melibatkan setiap orang yang berada di wilayah Indonesia terlibat dalam Pilkada DKI Jakarta tahun 2017.

Kasus yang terjadi di Pilkada DKI Jakarta tahun 2017 merupakan bukti dari penguasaan wacana yang begitu sistematis dan terarah dari pihak-pihak pengusung nilai-nilai fundamental, radikal, sekular atau liberal yang terjadi di

\footnotetext{
${ }^{4}$ Novia Ika Setiyani, Penggunaan Media Sosial sebagai Sarana Komunikasi Komunitas (Jurnal Ilmu Komunikasi: Universitas Sebelas Maret, Surakarta. 2013), h. 2
} 
media sosial. Bahkan menurut Herbert Mercuse, "Dapatkah seseorang dapat membedakan antara media massa sebagai sarana informasi dan hiburan dengan media massa sebagai agen maniulasi dan indoktrinasi",5 Sehingga dapat disimpulkan, hari ini terjadi sebuah dikotomi terhadap fungsi dari media sosial itu sendiri.

Oleh karena itu peneliti mencoba melakukan studi kasus terhadap perang dakwah yang terjadi di media sosial, dalam hal ini yang terdapat di Twitter berdasarkan atas wacana, opini, berita-berita di situs online, video dan komentar dari beberapa akun yang terlibat dari perang dakwah ini yang terjadi sebelum pemilihan gubernur di Pilkada DKI Jakarta tahun 2017. Meskipun pada akhirnya pada penelitian ini akan memunculkan sebuah fakta yang tidak hanya akan berdampak positif, tetapi juga akan memunculkan fakta negatif tentang proses dakwah hari ini yang terjadi di media sosial.

\section{KAJIAN TEORITIK}

\section{A. Objek Kajian Dakwah}

Objek kajian dakwah pada umumnya merupakan kegiatan yang mengajak mad'u kepada amar makruf nahi mungkar. Ajakan yang dimaksud berupa media yang dapat digunakan untuk mempermudah proses berdakwah. Bentuk ajakan tersebut yaitu': Pertama, mengajak dengan lisan ( $d a{ }^{6}$ wah bi al-lisan). Mengajak dengan lisan adalah metode dakwah yang dilakukan dengan cara pendekatan persuasive melalui media lisan antara dai dengan mad'u, pendekatan tersebut terbagi dua, yaitu secara individu maupun secara kolektif (ceramah). Dakwah lisan menjalin relasi langsung antara penutur/ daidengan mad'u dimana isi/ materi akan dikomunikasikan bersama dengan intonasi, bahasa tubuh dan emosi yang terkomuikasikan dalam relasi lisan tersebut.

Kedua, mengajak dengan tulisan ( $d a$ 'wah bi al-qalam) adalah metode dakwah yang dilakukan secara tidak lansung dengan proses face to face, akan tetapi melalui tulisan-tulisan yang dibuat oleh daiyang berisi tentang pesan dakwah yang selanjutnya disebar dan dibagikan kepada mad'u. Dakwah tulisan, dimediasi oleh media perantara yang biasanya bahasa tubuh, emosi menjadi berjarak antara penyampai pesan / daidengan mad'u. Pesan dakwah tulisan yang ditangkap/ diterima dan diresapi mad'u biasanya lebih ditentukan oleh pemahamanan dan keterampilan mad'u untuk menginterpretasikan pesan dakwah yang tertulis tersebut.

Ketiga, mengajak dengan perbuatan (da'wah bi al-hal atau aksi sosial). Mengajak dengan perbuatan dimaksudkan bahwa dakwah tersebut dilakukan dalam bentuk kegiatan-kegiatan sosial masyarakat, misalnya dengan membantu

${ }^{5}$ Herbert Mercuse, One Dimensional Man, terj. Silvester G. Sukur dan Yusup Priyasudiarja Manusia Satu Dimensi (Yogyakarta. Cempaka Putih. 2016) h. 13

${ }^{6}$ Amrullah Ahmad, Materi dan Metode Penyiapan Disiplin Dakwah Islam dalam Kurikulum IAIN 1995 dalam M. Tata Taufik, Dakwah Era Digital, (e-book edition; Ciawi: Pustaka Al Ikhlas, 2013), h. 11 
seseorang atau sekelompok masyarakat yang sedang mengalami musibah dengan ikhlas dan semata-mata hanya mengharap ridha Allah swt, sehingga perbuatan baik tersebut pada akhinrya dapat memperoleh simpati dari masyarakat. Masyarakat yang melihat hal tersebut pada akhinrya akan melakukan perbuatan baik yang serupa.

Pilihan terhadap bentuk-bentuk dakwah yang ditawarkan oleh para daikepada mad'u memberikan bukti bahwa pada hakikatnya jalan dakwah dapat ditempuh melalui beberapa cara dan pilihan tergantung kemampuan dari daidalam berinteraksi dengan mad'u. Legitimasi yang tidak tertulis di dalam masyarakat tentang bentuk-bentuk yang dapat dilakukan dalam proses berdakwah, bertujuan untuk memberikan kemudahan dalam mengidentifikasi posisi seseorang dalam berdakwah, cara yang digunakan, isi pesan dakwah, dan media yang paling tepat digunakan dalam menjaga efektifitas berdakwah. Sehingga pada akhirnya, prinsip dakwah yang merupakan hal yang mendasar dalam proses berdakwah dapat terlaksana.

\section{B. Media Sosial Twitter}

Twitter adalah salah satu media sosial lainnya yang tidak kalah populer dengan Facebook. Media sosial yang didirikan pada bulan Maret 2006 atas inisiasi dari Jack Dorsey, Noah Glass, Biz Stone dan Evan Williams sebagai sebuah proyek sampingan sebuah perusahaan iklan digital (podcasting) yang berada di San Fransico, Amerika Serikat. Pada bulan Juli tahun 2006 secara resmi layanan yang digunakan sebagai media komunikasi dalam sebuah kelompok kecil dengan menggunakan nama Twttr. Sebagai sebuah layanan pesan yang memiliki banyak karakteristik yang serupa dengan alat komunikasi lainnya yang sudah lamadigunakan, Twitter memiliki elemen yang mirip dengan email, IM, texting, blogging, RSS, jejaring sosial dan sebagainya.

Morris menyatakan bahwa: "Twitter is changing the way we talk to one another and the way businesses relate with clients, all within 140 characters or less"(Twitter mengubah cara kita berbicara satu sama lain dan cara bisnis berhubungan dengan klien, semuanya dalam 140 karakter atau kurang daripada itu). ${ }^{8}$

Asumsi ini lahir berdasarkan atas fungsi dari Twitter yang lahir sebagai sebuah perubahan dalam bentuk komunikasi intrapersonal manusia. Sedangkan, jumlah karakter 140 atau kurang daripada itu merujuk kepada batas (limit) yang disediakan oleh Twitter bagi seorang pengguna dalam menuliskan sebuah pesan atau status personalnya.

Twitter berada di atas semua sistem pesan publik yang tepat waktu. Setiap orang memiliki kemungkinan untuk mengatur konfigurasi akun yang dimilikinya

\footnotetext{
${ }^{7}$ Tim O'Reilly and Sarah Milstein.The Twitter Book (California: O’Reilly Media, Inc. 2009), h. 5-7

${ }^{8}$ Tee Morris, All a Twitter: A Personal and Professional Guide to Social Networking with Twitter (Indiana: Pearson Education, Inc. 2010), h. 8
} 
secara terbatas, sehingga akses pesan hanya dapat berlansung atas otorisasi yang dimilikinya. ${ }^{9}$ Pendapat Abou memberikan gambaran bahwa pada dasarnya Twitter memiliki persamaan dengan media sosialnya, yaitu setiap pengguna wajib memiliki akun terlebih dahulu, dan selanjutnya untuk melakukan komunikasi satu sama lain diperlukan pengaturan konfigurasi dalam hal meminta dan menerima pertemanan dari pengguna lainnya.Akan tetapi, lebih jauh Abou berpendapat bahwa Twitter merupakan media penyampai pesan yang tepat waktu, karena para pengguna cenderung akan mengungkapkan segala sesuatu yang berhubungan dengan dirinya dan lingkungannya secara lansung dalam bentuk status yang dikenal dengan istilah "ciutan" (twiit).

Perbedaan lainnya yang dimiliki dan sekaligus menjadi ciri khas dari Twitter yaitu tidak tersedinya layanan aplikasi untuk berbincang (chatting) dengan penggunan lainnya secara lansung (instant messages), seperti yang terdapat di Facebook dan MySpace. ${ }^{10}$ Twitter membatasi pengguna hanya untuk membagikan pesan kepada khalayak. Media sosial ini hanya menyediakan kolom komentar dan simbol-simbol lainnya, seperti halnya media sosial lainnya yang dikenal dengan istilah reply Tweet (balasan Twitter).

Twitter memiliki keistimewaan yang menyebabkan media sosial ini banyak digemari oleh segenap elemen masyarakat yang aktif dalam berkomunikasi di dunia maya. Setidaknya terdapat lima keunggulan yang dimiliki Twitter yaitu: ${ }^{11}$

Ambient Intimacy (keintiman sekitar) memberikan peluang kepada pengguna untuk menyebarkan pesan atau informasi kepada pengguna lain tentang kondisi sekitarnya secara pribadi/ intim tanpa harus mendapatkan respon dari orang lain. Pesan tersebut dapat berupa informasi kepada orang lain yang beruapa ajakan untuk melakukan sesuatu atau peringatan untuk menghindari sesuatu.

Sharing News and Commentary (berbagi berita dan komentar) berarti bahwa terjadi distribusi ide tentang apa yang sebuah informasi yang seorang pengguna pikirkan dan dapatkan serta apa pesan yang dapat dipahami oleh pengguna lainnya. Kesemuanya akan tertuang dalam layanan berbagai berita dan komentar di Twitter.

Breaking News and Shared Experiences (berita terbaru dan berbagi pengalaman) memposisikan Twitter sebagai media berita yang paling tepat waktu dalam menyampaikan pemberitaan. Setiap berita terbaru akan segera dibagikan oleh seseorang atau suatu lembaga di Twitter lebih dulu dibandingkan dengan pemeberitaan yang dilakukan melalui media pemberitaan konvesional lainnya. Selain itu, Twitter juga menjadi media dalam berbagi pengalaman tentang

\footnotetext{
${ }^{9}$ Oliver Abou, Twitter (Paris: Micro Application. 2009), h. 6

${ }^{10}$ Tee Morris, All a Twitter: A Personal and Professional Guide to Social Networking with Twitter (Indiana: Pearson Education, Inc. 2010), h. 16

${ }^{11}$ Tim O'Reilly and Sarah Milstein. The Twitter Book (California: O'Reilly Media, Inc. 2009), h. 9-17
} 
informasi apa saja, baik tentang kondisi cuaca, situasi ekonomi, politik bahkan sebuah rencana kegiatan dapat dibagikan di Twitter.

Mind Reading (membaca pikiran) dapat dilakukan dengan bantuan Twitter karena seorang pengguna tidak hanya berfokus pada apa yang dipikrikan oleh sesorang melalui status yang dibagikan, akan tetapi juga dapat melihat dikelompok atau golongan mana mereka berada di masyarakat. Kecenderungan seorang pengguna terhadap kesepahaman atau tidaknya terhadap suatu kelompok dapat dianalisa melalui status yang mereka bagikan kepada khalayak.

Business Conversations (percakapan bisnis) dapat terjadi di Twitter melalui hubungan komunikasi/ percakapan bisnis yang terjalin antara sebuah perusahaan dengan para pelanggannya, atau antara penyedia jasa layanan terhadap kliennya. Kepuasan dan keluhan terhadap produk/ layanan sebuah perusahaan dapat ditanyakan lansung pada akun perusahaan yang ada di Twitter, dan perusahaan dapat memberikan klarifikasi dan jawaban secara lansung dengan membalas stauts dari pelanggan tersebut. Hal ini dilakukan demi terjadi hubungan sinergitas antara perusahaan dengan pelanggannya.

Setelah memahami keunggulan yang dimiliki oleh Twitter, selanjutnya akan dibahas tentang bagaimana cara menggunakan layanan media sosial ini yang dimulai dari cara untuk mendaftar (sign up), masuk ( $\log$ in), menemukan teman (follow), membuat status/ ciutan (tweet), merespon/ membalas status seseroang (respon/ reply), dan membagikan kembali status seseorang (retweet).

\section{Sign $U p$}

Seperti halnya media sosial lainnya, untuk menggunakan layana Twitter, setiap calon pengguna diwajibkan untuk melakukan proses pendaftaran (sign up) terlebih dahulu dengan cara mengisi form yang telah disediakan di halaman awal Twitter. Calon pegguna cukup melakukan registrasi dengan mencantunkan nama lengkap, alamat email atau nomor ponsel dan kata sandi.

Nama lengkap yang diisi bertujuan untuk menyesuaikan nama pengguna yang akan digunakan sebagai akun di Twitter. Alamat email atau nomor ponsel bertujuan sebagai media penghubung antara pengguna dengan pihak Twitter untuk melakukan notifikasi ulang dan informasi-informasi lainnya yang bersifat personal antara pengguna dengan pihak Twitter. Kata sandi (password) digunakan sebagai kunci untuk masuk di akun Twitter miliknya. Tampilan halaman sign up (pendaftaran) Twitter adalah sebagai berikut: 
Gambar. 7

Tampilan halaman Sign $U p$

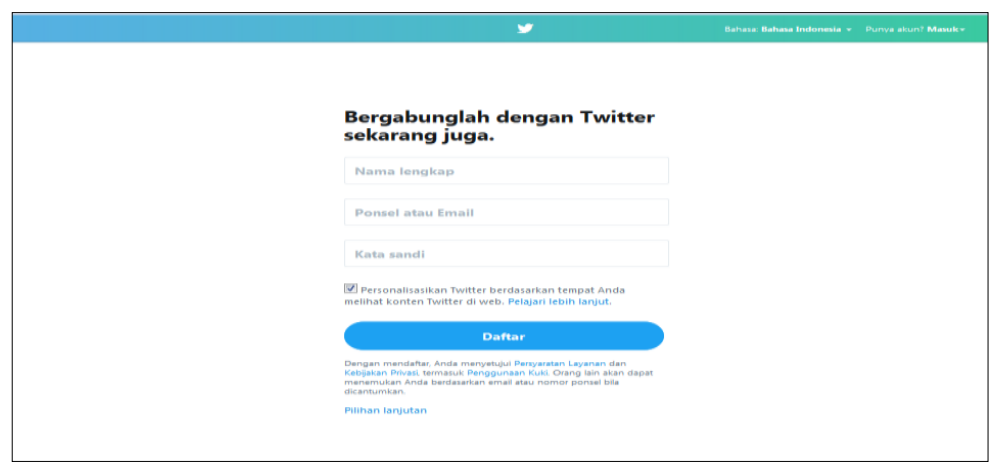

Sumber: Tampilan halaman Sign Up di Twitter ${ }^{12}$

2. $\log \operatorname{In}$

Pengguna yang telah melakukan proses pendaftaran dan telah menerima balasan notifikasi melalui email atau nomor ponsel dari pihak Twitter, selanjutnya dapat masuk melalui halaman log in (masuk) menggunakan nama pengguna, email atau nomor ponsel yang digunakan pada saat mendaftar. Kata sandi menjadi kunci/ penanda bagi pihak Twitter bahwa pihak yang bersangkutan adalah pengguna yang sah dari akun Twitter tersebut. Apabila pengguna lupa kata sandinya, maka disediakan sebuah layanan untuk meminta ulang kata sandi dengan cara memasukkan alamat email atau nomor ponsel yang dapat dikrimi notifikasi oleh pihak Twitter. Tampilan halaman $\log$ in (masuk) adalah sebagai berikut:

Gambar. 8

Tampilan halaman Log In

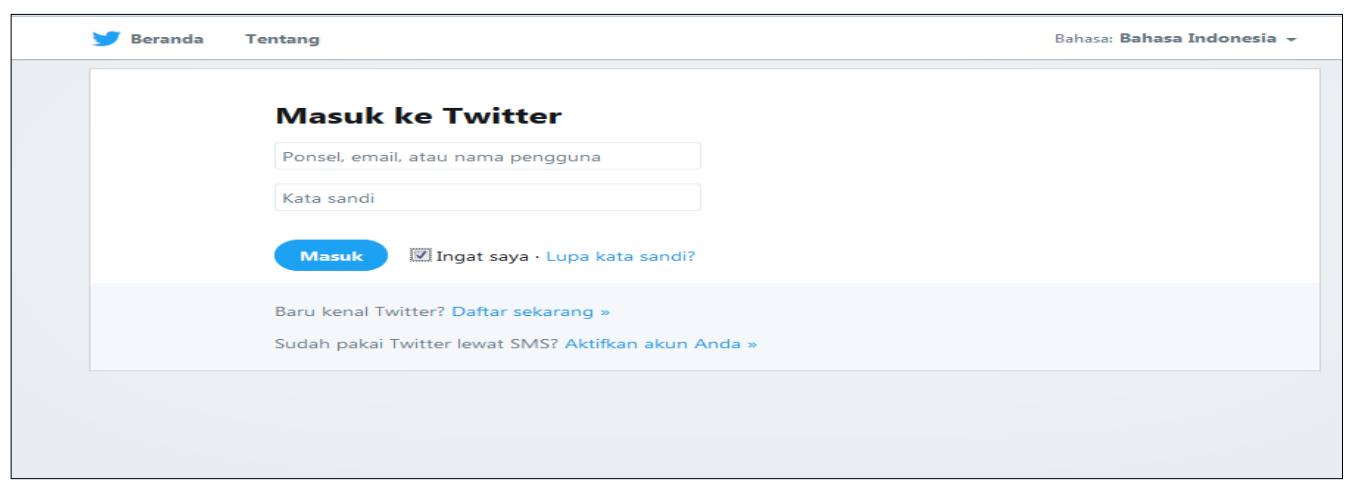

Sumber: Tampilan halaman Log In di Twitter ${ }^{13}$

3. Follow

Twitter menggunakan istilah follow (mengikuti) untuk menghubungkan antara penguna yang satu dengan pengguna yang lainnya. Setiap pengguna yang

${ }^{12}$ https://twitter.com/signup?lang=id. Diakses pada tanggal 17 Agustus 2017 pukul 23.50

${ }^{13}$ https://twitter.com/login?lang=id. Diakses pada tanggal 17 Agustus 2017 pukul 24.08 
ingin membuat pertemanan, terlebih dahulu melakukan pencarian nama di kolom pencarian yang telah disediakan. Pengguna yang ingin menjadikan pengguna lain sebagai teman, mengklik tulisan "follow" yang berada disebelah nama akun tersebut. Seseorang yang mengikuti pengguna lain diistilahkan dengan "follower" (pengikut), sedangkan pengguna yang diikuti diistilahkan dengan "following" (yang diikuti). Pengguna yang diikuti dapat mengikuti balik atau tidak pengguna lainnya yang telah menjadi follower.Tampilan halaman follow, follower, dan following adalah sebagai berikut:

Gambar. 9

Tampilan halaman follow, follower, dan following

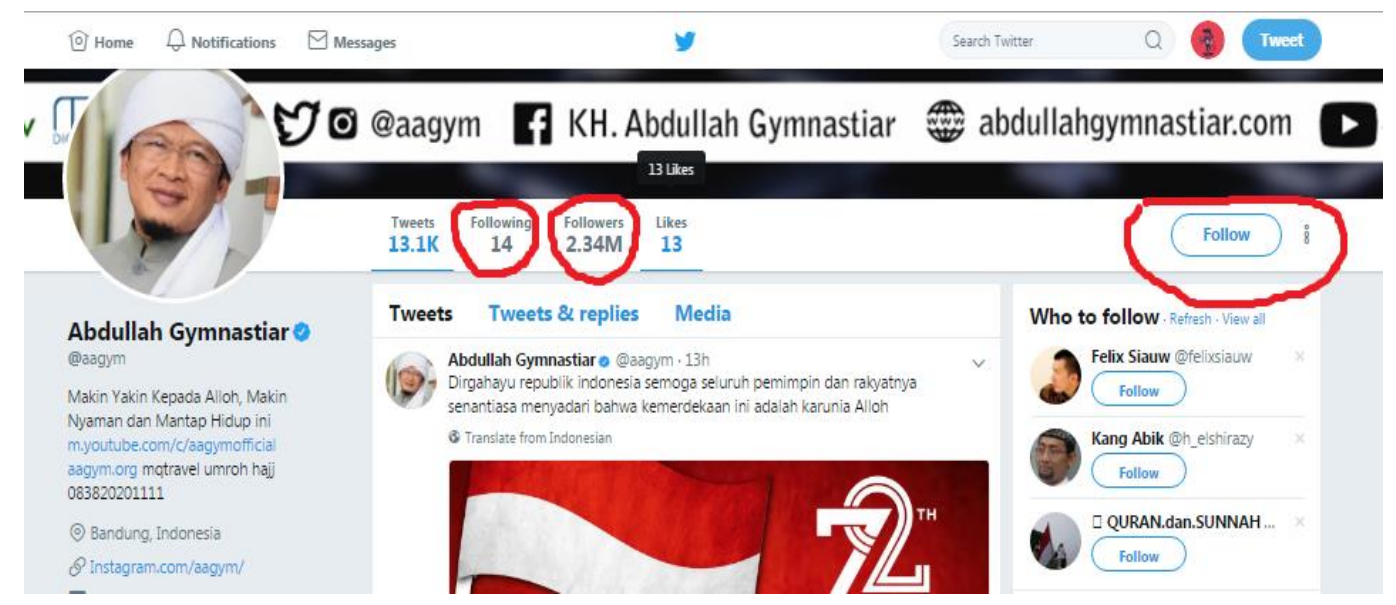

Sumber: Tampilan halaman follow, follower, dan following di Twitter ${ }^{14}$

\section{Tweet}

Status yang dibagikan oleh seorang pengguna pada dinding Twitternya dikenal dengan istilah tweet (ciutan). Kolom tweet (ciutan) berbeda dengan dengan kolom status yang ada di Facebook, karena pengguna hanya dibatasi sampai dengan 140 karakter tulisan. Setiap pengguna berhak untuk melampirkan foto, video, suara, simbol dan lokasi bersamaan dengan tulisan di kolom tersebut. Pengguna yang cukup mengklik tulisan tweet yang berada di bawah kolom untuk membagi statusnya kepada khalayak. Tampilan halaman tweet adalah sebagai berikut:

\footnotetext{
${ }^{14}$ https://twitter.com/aagym. Diakses pada tanggal 17 Agustus 2017 pukul 24.32
} 
Gambar. 10

Tampilan halaman tweet

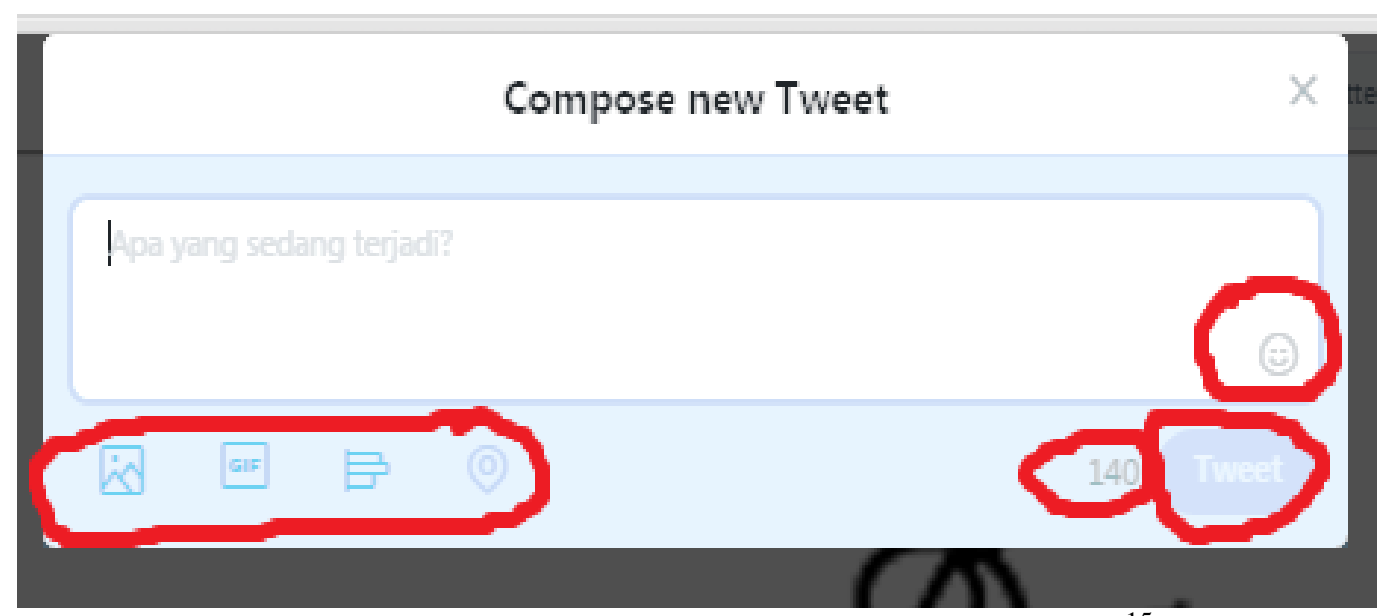

Sumber: Tampilan halaman halaman tweet di Twitter $^{15}$

\section{Respon/Reply}

Walaupun bukanlah sebuah hal yang mutlak bahwa setiap status personal yang dibagikan melalui Twitter, secara lansung menginginkan adanya tanggapan atau balasan (respon/ reply) dari pengguna lainnya, tetap saja setidaknya ada harapan bahwa pesan yang tersirat di dalam sebuah status personal yang telah dibaca oleh pengguna dapat memperoleh tanggapan atau balasan sebagai bukti bahwa pesan tersebut telah sampai kepada khalayak. Umpan balik yang diberikan oleh pengguna lainnya dapat berupa komentar yang dituliskan pada kolom komentar atau untuk sekedar menyukai status personal tersebut, cukup dengan mengklik simbol "hati" yang berarti pengguna lainnya menyukai statusnya. Contoh tampilan status personal yang mendapatkan respon/ replydari pengguna lain adalah sebagai berikut:

\section{Gambar. 11}

\section{Contoh status yang mendapatkan respon/ reply}

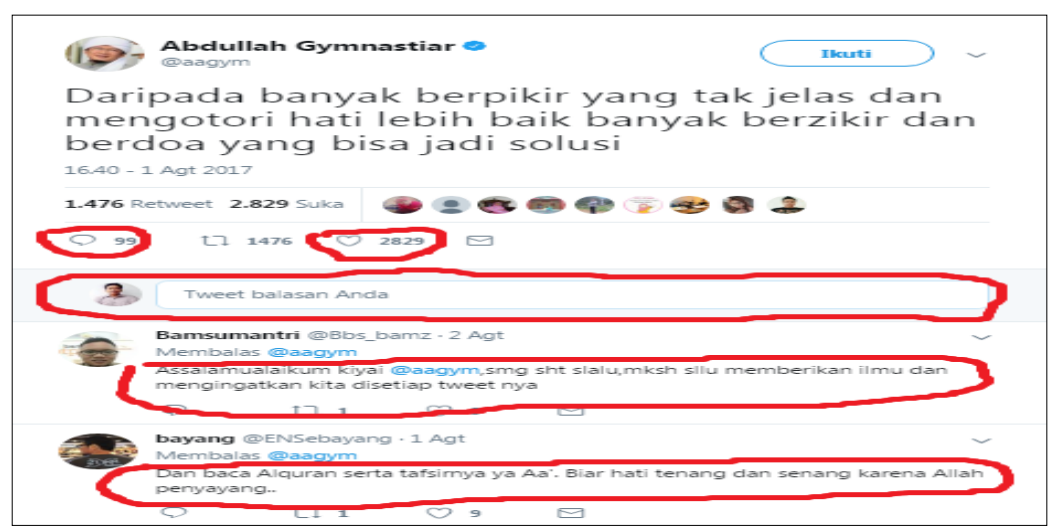

Sumber: Tampilan halaman halaman tweet di Twitter $^{16}$

${ }^{15}$ https://twitter.com/Tajibarani21. Diakses pada tanggal 17 Agustus 2017 pukul 24.52 


\section{Retweet}

Salah satu layanan yang disediakan oleh Twitter yaitu layanan membagikan kembali status seseorang atau dikenal dengan istilah "retweet" (tweetulang). Retweet dilakukan oleh pengguna lain apabila status personal tersebut menarik atau bersifat informatif sehingga setiap pengguna lainnya juga harus tahu akan hal tersebut. Seperti halnya membuat status personal, pada kolom retweet, pengguna juga dapat menuliskan kalimat sebanyak 140 karakter untuk mengomentari status tersebut. Contoh tampilan retweet dari pengguna lain adalah sebagai berikut:

Gambar. 12

Contoh tampilan retweet
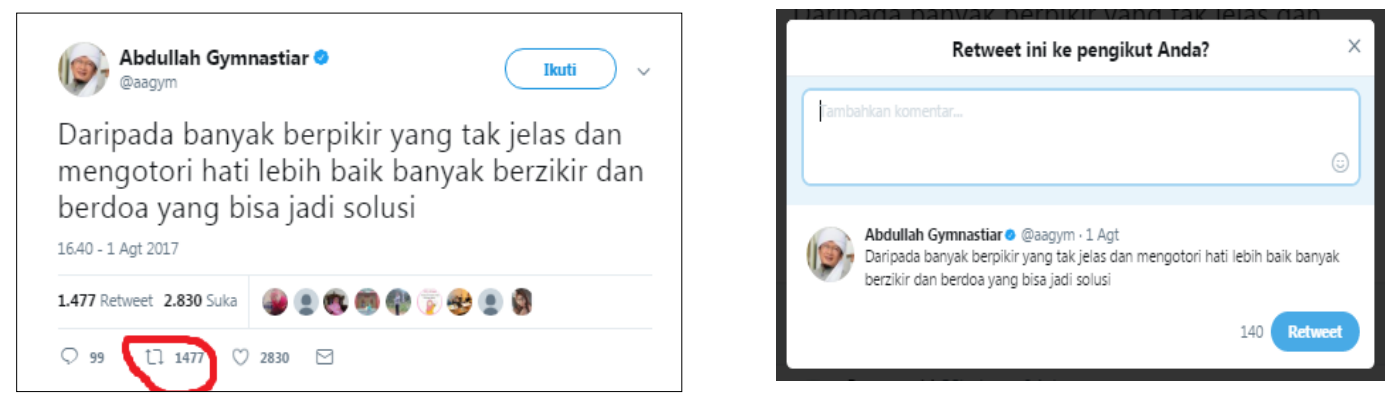

Sumber: Tampilan halaman halaman tweet di Twitter $^{17}$

Para pengguna Twitter pada umumnya menandai sebuah status yang sedang menjadi berita/ pembicaraan hangat (trending topic) dengan mengunakan tanda pagar (hastag) “\#” di depan kata yang dijadikan sebagai topik perbicanggan para pengguna Twitter. Fungsi dari tanda ini adalah untuk menandai tentang perbicangan di suatu kelompok atau komunitas adalah sesuatu yang penting untuk disimak. Semakin banyak pengguna yang menggunakan tanda tersebut, maka semakin sering pihak Twitterakan menginfokannya kepada khalayak pada halaman beranda. Contoh penggunaan tanda "\#” adalah sebagai berikut:

\footnotetext{
${ }^{16}$ https://twitter.com/aagym/status/892530618654801920. Diakses pada tanggal 18 Agustus 2017 pukul 19.02

${ }^{17}$ https://twitter.com/aagym/status/892530618654801920. Diakses pada tanggal 18 Agustus 2017 pukul 19.51
} 
Gambar. 13

Contoh tampilan tanda "\#”

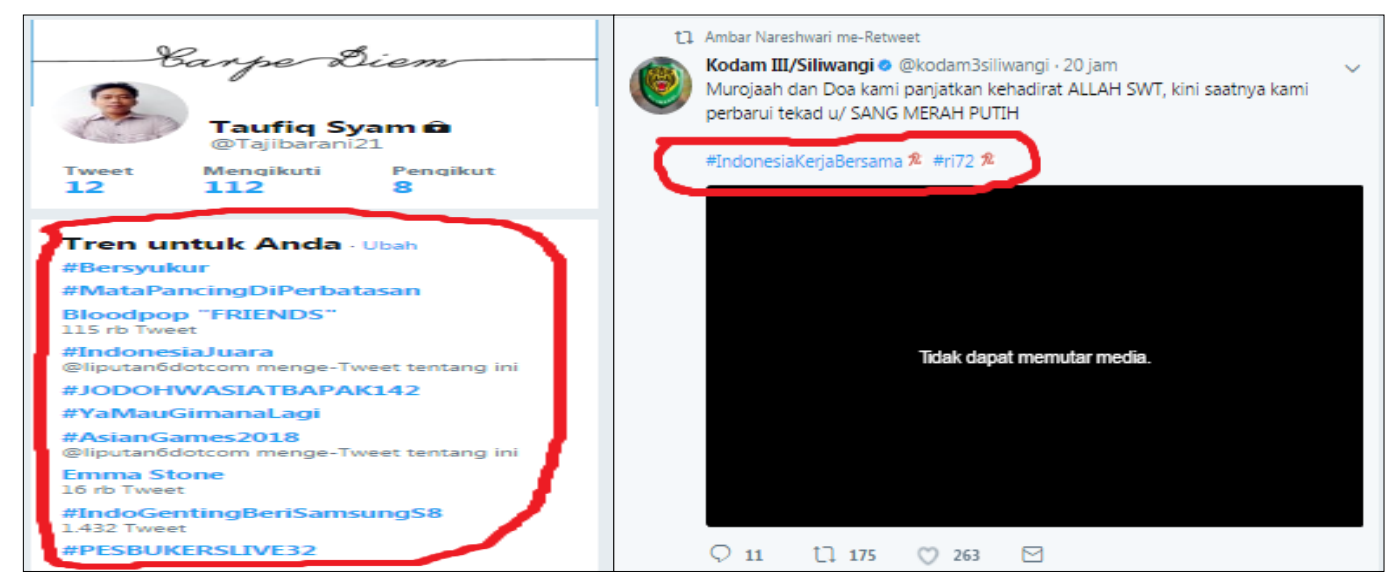

Sumber: Tampilan tanda “\#”di Twitter ${ }^{18}$

\section{METODOLOGI PENELITIAN}

Jenis penelitian ini adalah penelitian kualitatif atau naturalistik. Pendekatan penelitian ini adalah pendekatan sosioligi komunikasi dalam bentuk studi kasus (case study) terhadap arena produksi kultural merujuk pada konsep, pendapat, pemikiran, dan komentar para da`i maupun masyarakat dalam bentuk tulisan, berita/ wacana, pesan gambar, status personal, komentar terhadap status seseorang dan video ceramah dan debat dakwah yang diunggah ke media sosial yang nantinya akan menggiring opini publik ke dalam ranah pembentukan mindset kecenderungan (disposisi) terhadap suatu otoritas (authority) yang sedang terjadi.

Lokasi penelitian ini adalah media sosial terkhusus pada media sosial yang sering digunakan yaitu Facebook. Sumber data pada penelitian dari informan yang digunakan dalam penelitian ini yaitu para pengguna media sosial Tweeter. Teknik pengumpulan data adalah observari, dokumentasi. Instrumen penelitian adalah pedoman observasi dan alat dokumentasi. Proses pengujian keabsahan data terdiri kredibilitas, transferbilatas, depenbilitas dan konfimabilitas. Teknik pengolahan dan analisis data terdiri dari reduksi data, display data, dan verifikasi atau penarikan kesimpulan.

\section{HASIL PENELITIAN DAN PEMBAHASAN}

Twitter sebagai sebuah media sosial yang belakangan ini semakin banyak digemari oleh para pengguna media sosial, telah menjadi salah satu media untuk menyebarkan pesan-pesan dakwah. Para dai atau siapa pun yang mempunyai kapabilitas untuk menyebarkan pesan dakwah, dapat menggunakan twitter untuk berinteraksi dengan khalayak (mad'u). Dalam perhelatan momentum Pilkada DKI Jakarta tahun 2017 lalu, twitter juga memiliki peranan penting dalam

\footnotetext{
${ }^{18}$ https://twitter.com. Diakses pada tanggal 18 Agustus 2017 pukul 20.13
} 
penyebarluasan pesan-pesan yang berkaitan dengan momen tersebut. Untuk memperjelas peran twitter dalam mentransformasikan bentuk dakwah, maka peneliti akan menjelaskan sebagaimana berikut:

\section{Unsur Dakwah}

Di media sosial Twitter, seperti halnya yang terdapat pada media sosial Facebook yang sebelumnya peneliti deksripsikan, bentuk transformasi dakwah dapat kembali dijelaskan sebagai berikut:

a. Subjek dakwah (dai)

Para dai yang menjadi subjek dari dakwah di media sosial di dalam Pilkada DKI Jakarta, adalah para pengguna media sosial Twitter. Para tokoh agama/ dai, akademisi, penulis dan public figure lainnya yang di dalam kehidupan sehari-hari mendakwahkan ajaran-ajaran Islam secara lansung kepada umat muslim, pada umumnya akan membuat sebuah account (identitas) di Twitter.

Contoh bentuk account (identitas) dari para dai yang ada di media sosial Twitter, antara lain sebagai berikut:

\section{Gambar. 43 \\ Contoh account (identitas) dai di Twitter}

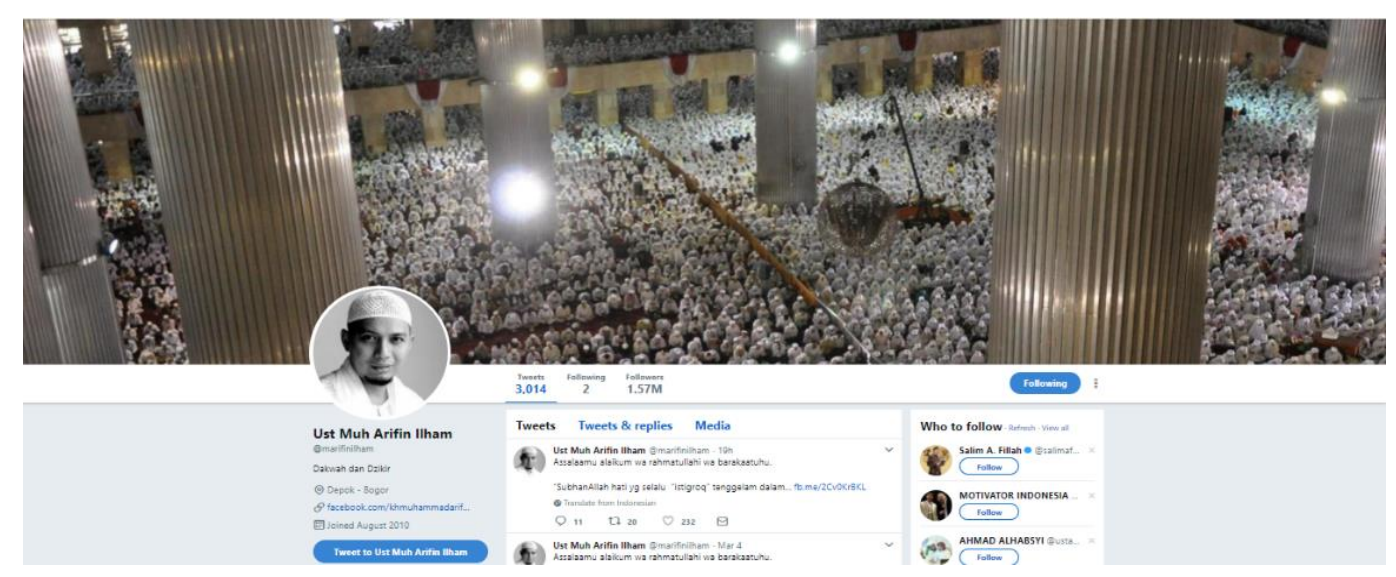

Sumber: Account (identitas) Ust. Muh. Arifin Ilham di Twitter ${ }^{19}$

Berbeda dengan akun yang berada di media sosial Facebook, di Twitter tidak disediakan layanan untuk membuat fan page account (akun untuk penggemar). Hal ini disebabkan karena adanya salah satu prinsip yang dijalankan oleh Twitter yaitu ambient intimacy (keintiman sekitar) yang memberikan peluang kepada pengguna untuk menyebarkan pesan atau informasi kepada pengguna lain tentang kondisi sekitarnya secara pribadi/ intim tanpa harus ada batasan hanya terkhusus bagi penggemar.

Contoh lain dari bentuk account (identitas) dari para dai yang ada di media sosial Twitter yaitu:

\footnotetext{
${ }^{19}$ Sumber Data 31: https://twitter.com/marifinilham. Diakses 07 Maret 2018 Pukul 10.11
} 
Gambar. 44

Contoh lain account (identitas) dai di Twitter

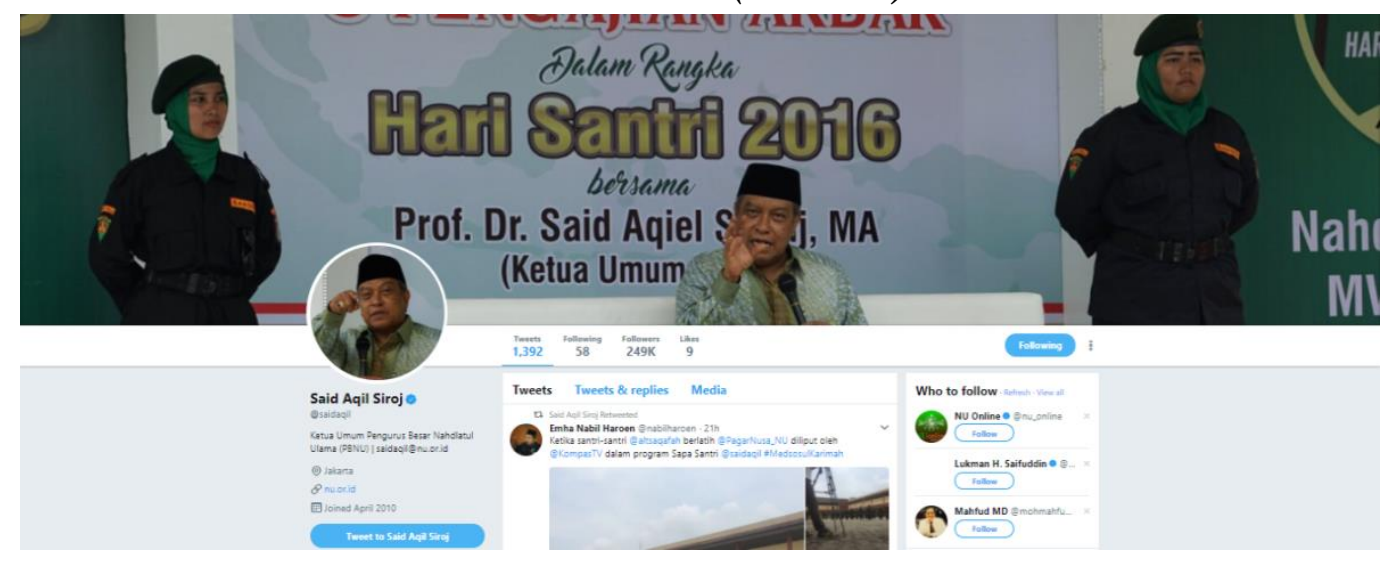

Sumber: Account (identitas) KH. Said Aqil Siroj di Twitter ${ }^{20}$

Persamaan antara media sosial Facebook dan Twitter yang dapat dilihat dari kedua contoh account (identitas) dai yang aktif di media sosial tersebut adalah penggunaan tanda "@”, yang digunakan sebagai di awal nama pengguna, seperti “@marifinilham”dan “@saidaqil” dapat digunakan oleh pengguna lainnya untuk memudahkan mencari account (identitas) dai, akademisi, penulis dan public figure lainnya di Twitter.

Peneliti juga mengambil data dari beberapa akun dari para tokoh agama Islam, penulis dan akademisi lainnya di Twitter selain dari kedua dai di atas. Mereka adalah KH. Abdullah Gymnastiar (Aa Gym), Habib Rizieq Shihab, Buya Safii Maarif, KH. Ahmad Mustofa Bisri (Gus Mus), Sohibul Iman, Prof. Azumardi Azra, Ulil Absar Abdallah, Ust. Bachtiar Nasir, Akhmad Sahal, dan Nusron Wahid.

b. Objek dakwah (mad`u)

Para pengguna media sosial Twitter lainnya yang mengikuti (follower) akun-akun dari para dai, akademisi, penulis dan public figure tersebut juga dapat diistilahkan sebagai objek dakwah atau sasaran dakwah (mad'u). Mereka inilah yang akan menerima pesan-pesan dakwah yang disebarkan oleh para dai di media sosial Twitter yang berhubungan dengan Pilkada DKI Jakarta tahun 2017.

Contoh objek dakwah (mad'u) yang terdapat di Twitter dapat dilihat berdasarkan gambar berikut ini:

${ }^{20}$ Sumber Data 32: https://twitter.com/saiqaqil. Diakses 07 Maret 2018 Pukul 11.09 
Gambar. 45

Contoh jumlah objek dakwah/ pengikut (followers) di Twitter
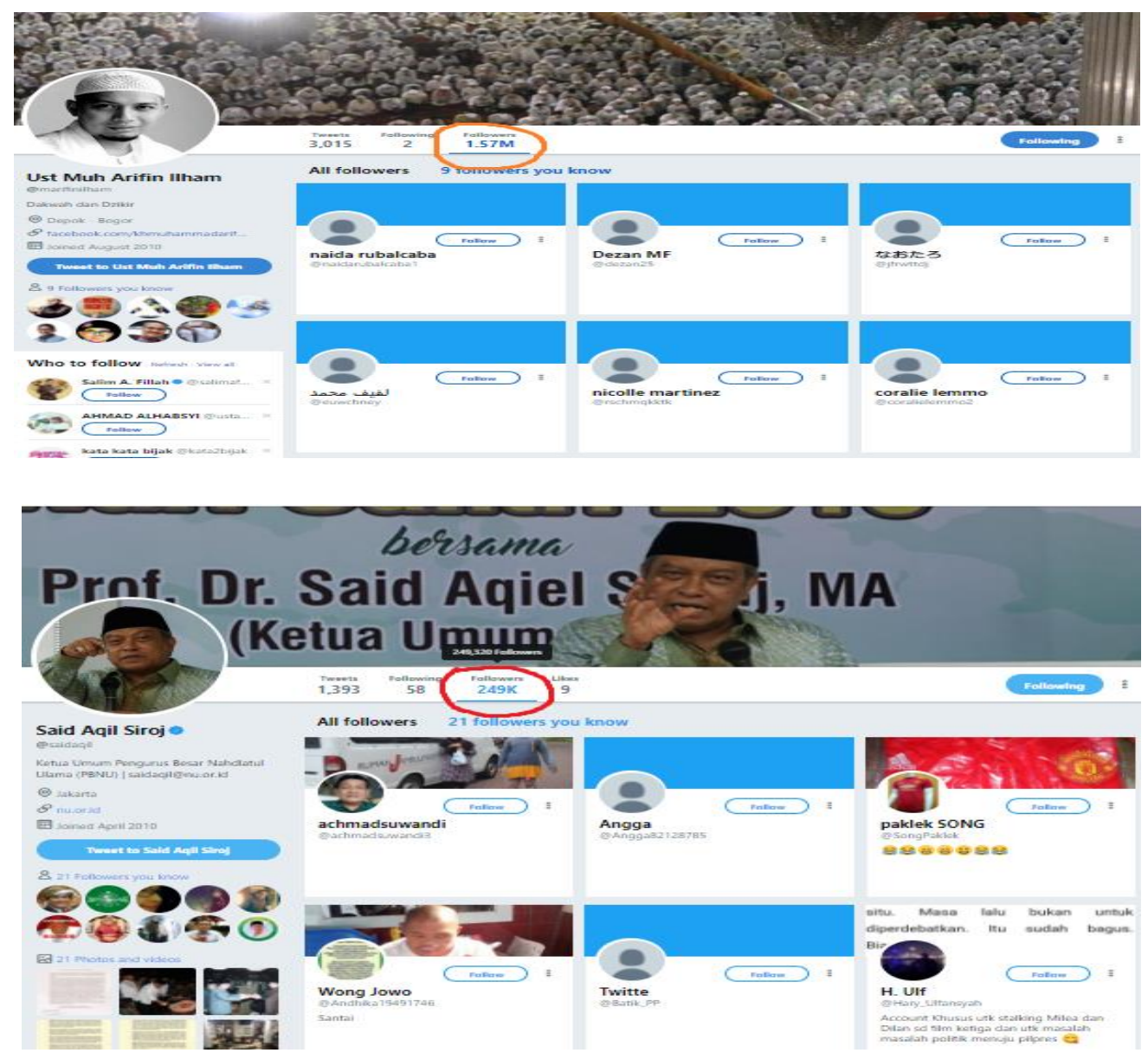

Sumber: Jumlah dan tampilan follower (pengikut) account Ust. Muh. Arifin Ilham $^{21}$ dan KH. Said Aqil Siroj di Twitter ${ }^{22}$

Transformasi jumlah objek dakwah (mad'u) yang terdapat di Twitter dapat dilihat berdasarkan dari banyak jumlah pengikut (followers) dari kedua contoh akun di atas. Untuk akun milik Ust. Muh. Arifin Ilham Mustofa Bisri terdapat sebanyak 1.570.000 pengguna lainnya yang dapat diklaim sebagai objek dakwah (mad'u). Sedangkan untuk akun penggemar yang di miliki oleh KH. Said Aqil Siroj sebanyak 249.000 pengguna lainya yang dapat diklaim sebagai objek dakwah (mad'u) di media sosial. Secara detail, jumlah dari pengikut (follower) dari beberapa akun dari para tokoh agama Islam, penulis dan akademisi lainnya yang dijadikan data oleh peneliti adalah sebagai berikut.

\footnotetext{
${ }^{21}$ Sumber Data 32: https://twitter.com/marifinilham/followers. Diakses 07 Maret 2018 Pukul 09.09

${ }^{22}$ Sumber Data 32: https://twitter.com/saiqaqil/followers. Diakses 07 Maret 2018 Pukul 09.15
} 
Tabel 4.

Jumlah followers (pengikut) dari akun Twitter sample. ${ }^{23}$

\begin{tabular}{|l|l|c|c|}
\hline No & \multicolumn{1}{|c|}{ Nama Akun } & Type Akun & Jumlah Followers \\
\hline 1 & KH. Abdullah Gymnastiar & Active Account & 2.590 .000 \\
\hline 2 & Ust. Muh. Arifin Ilham & Active Account & 1.570 .000 \\
\hline 3 & KH. Ahmad Mustofa Bisri & Active Account & 1.170 .000 \\
\hline 4 & Ulil Absar Addallah & Active Account & 771.000 \\
\hline 5 & KH. Said Aqil Siroj & Active Account & 249.000 \\
\hline 6 & Akhmad Sahal & Active Account & 154.000 \\
\hline 7 & Ust. Bachtiar Nasir & Active Account & 142.000 \\
\hline 8 & Nusron Wahid & Active Account & 70.600 \\
\hline 9 & Habib Rizieq Shihab & Active Account & 42.900 \\
\hline 10 & Mohamad Sohibul Iman & Active Account & 34.300 \\
\hline 11 & Prof. Azumardi Azra & Active Account & 8.835 \\
\hline 12 & Buya Safii Maarif & Active Account & 6.628 \\
\hline
\end{tabular}

Sumber: Olahan Peneliti 2018.

Perbedaan antara Facebook dan Twitter dapat dilihat dari table di atas yaitu dalam tampilan detail informasi pengikut (followers). Di media sosial Facebook, jumlah followers akan ditampilkan detail hingga di jumlah satuan, sedangkan di Twitter jika angka followers sudah menjadi puluhan ribu maka hanya menampilkan sampai jumlah akumulatif. Hal ini terjadi karena pihak Twitter dapat memberikan layanan yang dapat menampung jumlah followers (pengikut) yang tidak terbatas disetiap akun sehingga tidak memberikan jumlah detail akun pengguna lainnya yang menjadi followers.

\section{c. Metode dakwah}

Merujuk kepada penggunaan metode dakwah selama masa Pilkada DKI Jakarta tahun 2017 di Facebook, metode yang sama juga dapat ditemukan di media sosial Twitter. Metode-metode berdakwah dengan metode dakwah hikmah, metode dakwah mauidzah hasanah (nasihat), metode dakwah mujadalah (berdebat), dan metode dakwah qudwah hasanah (keteladan) tetap digunakan oleh para dai untuk menyebarkan pesan-pesan dakwah yang berhubungan dengan kepemimpinan yang tepat di Pilkada DKI Jakarta nantinya yang sesuai dengan ajaran Islam di Twitter.

Para public figure saling menyebarkan pesan-pesan dakwah, yang di Twitter diistilahkan dengan "ciutan" (tweet). Penggunaan transformasi metodemetode dakwah tersebut tidak lain bertujuan untuk menyampaikan kepada khalayak tentang persepsi mereka masing-masing. Beberapa contoh metode dakwah yang digunakan oleh para dai dapat dilihat dalam gambar berikut:

\footnotetext{
${ }^{23}$ Sumber Data 35: https://www.twitter.com/. Diakses 21 Januari 2018 pukul 12.53
} 
Gambar. 46

Contoh metode dakwah hikmah

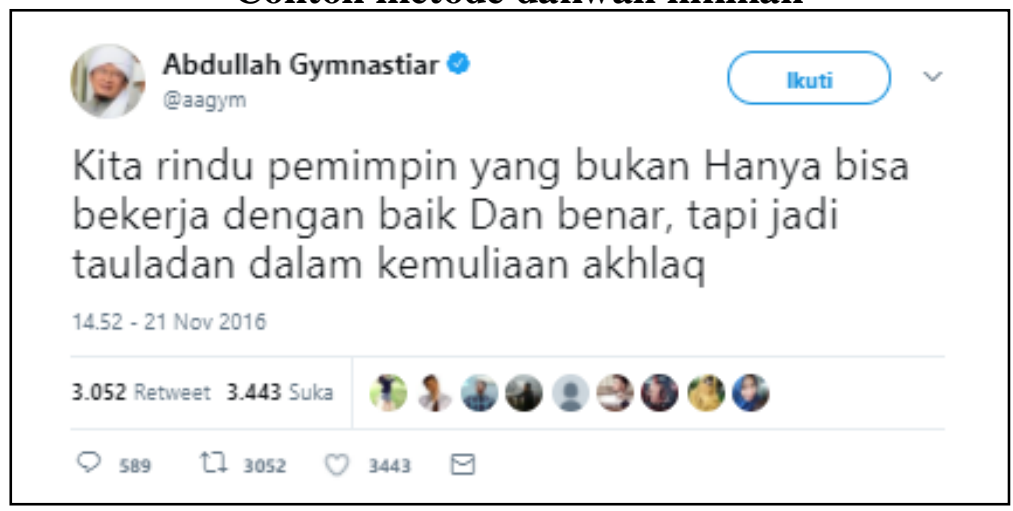

Sumber: Status (tweet) dari KH. Abdullah Gymnastiar tentang pemimpin ${ }^{24}$

Di dalam ciutan/ status di akun Twitter yang diunggah oleh KH. Abdullah Gymnastiar pada tanggal 21 November 2016, menunjukkan bentuk metode dakwah hikmah yang berusaha untuk memberikan pesant kepada mad'u tentang kebaikan, kejelasan dan kemudahan dalam memahami pesan dakwah yang diterima. Pesan dakwah yang disampaikan bertujuan untuk menyindir kepada salah satu kandidat gurbenur DKI Jakarta yang sedang menjabat yaitu Basuki Tjahaja Purnama (Ahok) yang selalu mengkampanyekan tentang keberhasilan kinerjanya, akan tetapi tidak dibarengi dengan sikap yang mulia dalam bertutur dan bersikap kepada orang lain. KH. Abdullah Gymnastiar mengungkapakan harapan dan kerinduannya terhadap sosok seorang pemimpin yang dapat menjadi teladan. Pesan ini secara bijaksana juga menghimbau seorang muslim harus menyatukan sikap dalam memilih pemimpin dengan kriteria tersebut di Pilkada DKI Jakarta nantinya.

Di akun Twitter lainnya, metode hikmah lainnya dapat dilihat dari status yang diunggah oleh KH. Ahmad Mustofa Bisri berikut ini:

Gambar. 47

Contoh metode dakwah hikmah lainnya

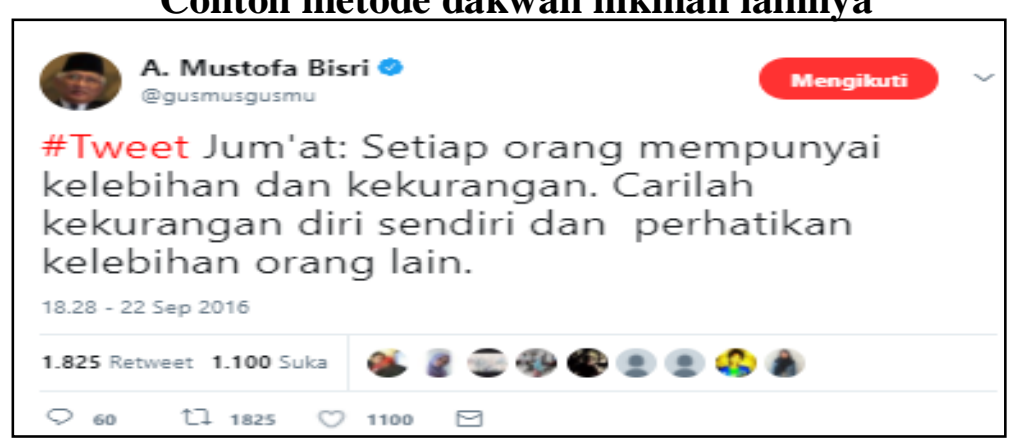

Sumber: Status (tweet) dari KH. Ahmad Mustofa Bisri tentang pemimpin ${ }^{25}$

\footnotetext{
${ }^{24}$ Sumber Data 36: https://www.twitter.com/aagym/status/. Diakses 31 Januari 2018 pukul 20.56
} 
Di dalam ciutan/ status di akun Twitter yang diunggah oleh KH. Ahmad Mustofa Bisri (Gus Mus) pada tanggal 22 September 2016, menunjukkan bentuk metode dakwah hikmah yang berusaha untuk menggambarkan tentang kebaikan kepada mad'u bahwa pada dasarnya manusia memiliki kelebihan dan kekurangan di dalam dirinya. Status ini memberikan penjelasan tentang perlunya mengingat kebaikan seseorang yang menjadi kelebihannya, dan pentingnya menyadari kekurangan diri sendiri sebagai bentuk introspeksi diri. Tujuan dari status $\mathrm{KH}$. Ahmad Mustofa Bisri agar umat muslim yang akan menghadapi moment Pilkada DKI Jakarta sebaiknya lebih bijaksana dalam menentukan pilihannya dan tidak hanya terus mencari kesalahan seorang pemimpin, akan tetapi juga mengingat kebaikan yang telah dia perbuat selama masa kepemimpinannya. Pesan ini disampaikan dengan wajar dan mudah dipahami sebagai perkataan yang baik dan jelas (qaulan maisūran) bagi khalayak.

Di samping metode dakwah hikmah, di Twitter juga dapat ditemukan bentuk transformasi metode dakwah mauidzah hasanah (nasihat) yang berhubungan dengan Pilkada DKI Jakarta tahun 2017.

Metode mauidzah hasanah yang berfokus pada nasihat baik yang berisi tentang pengajaran tentang penting menegakkan taqwa kepada Allah SWT, pentingnya menjaga hubungan baik dengan manusia dan peringatan tentang adanya ganjaran dosa dari setiap perbuatan yang menyimpang dan tidak sesuai dengan syariat agama Islam disampaikan dalam bentuk status dari para dai.

Contoh metode dakwah mauidzah hasanah (nasihat) dapat dilihat dari gambar-gambar berikut ini:

Gambar. 48

Contoh metode dakwah mauidzah hasanah (nasihat)

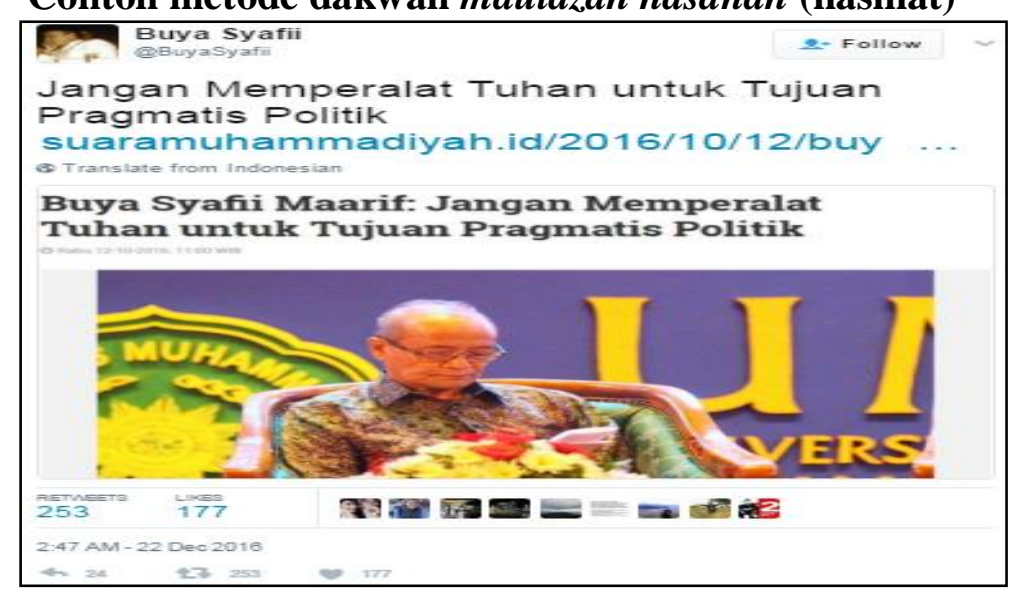

Sumber: Status (tweet) dari Buya Syafii Maarif tentang politik di Pilkada DKI Jakarta $^{26}$

\footnotetext{
${ }^{25}$ Sumber Data 37: https://www.twitter.com/gusmusgusmu/status/. Diakses 31 Januari 2018 pukul 20.56

${ }^{26}$ Sumber Data 38: https://www.twitter.com/BuyaSyaffi/status/. Diakses 05 April 2017 pukul 15.17
} 
Di dalam status yang ditulis oleh Buya Syafii Maarif di Twitter pada tanggal 22 Desember 2016, tampak sedang membagikan tulisannya yang dimuat dalam media online Suara Muhammadiyah. Di dalam pesan beliau, yang lebih jelasnya dapat dibaca dalam link media online Suara Muhammadiyah, sedang memberikan nasehat tentang larangan bagi setiap umat muslim untuk menggunakan nama Allah swt., dalam melakukan kegiatan politik. Hal ini disebabkan karena pada Pilkada DKI Jakarta, banyak oknum yang mengatasnamakan sebagai kelompok mayoritas/ muslim senantiasa mengkampanyekan untuk memilih pemimpin yang seakidah dengan menggunakan ayat-ayat dari Al Qur'an, yang semata-mata hanya untuk kepentingan politik semata. Pesan yang disampaikan tersebut dapat dikategorikan sebagai pesan yang mengandung term qaulan baligha karena pesannya yang dapat merasuk dan membekas dalam jiwa.

Di sisi lain, seorang dai yang juga merangkap sebagai ketua umum partai politik, Mohamad Sohibul Iman, juga aktif menyebarkan menyebarkan pesanpesan dakwah di akun Twitter miliknya. Salah satu contoh metode dakwah mauidzah hasanah (nasihat) dapat dilihat pada gambar berikut:

Gambar. 49

Contoh metode dakwah mauidzah hasanah (nasihat) lainnya

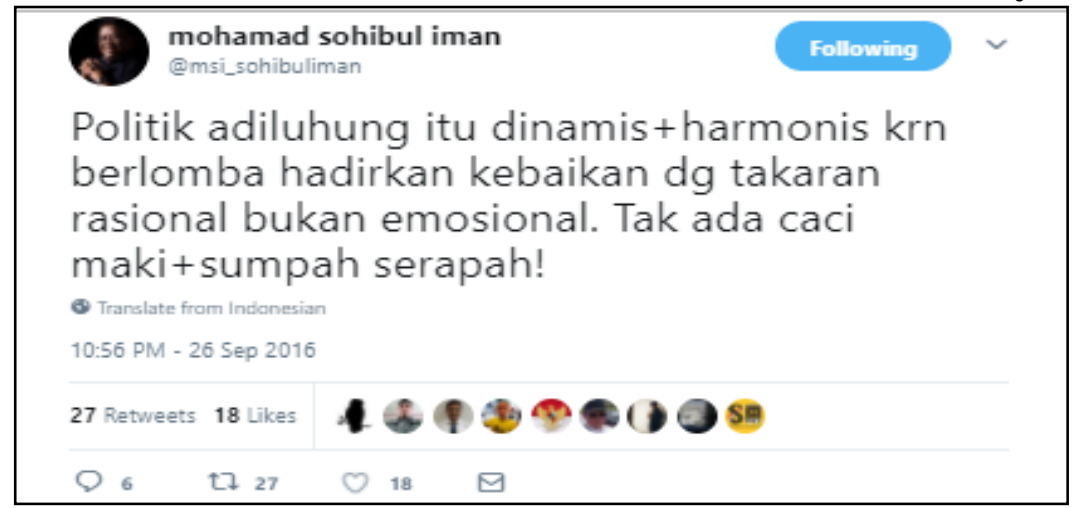

Sumber: Status (tweet) dari Mohamad Sohibul Iman tentang politik di Pilkada DKI Jakarta ${ }^{27}$

Di dalam status yang dibagikan oleh Mohamad Sohibul Iman pada tanggal 26 September 2016 di Twitter, beliau memberikan nasihat yang menggambarkan tentang politik yang bijaksana sebaiknya senantiasa memegang prinsip yang saling berdinamis dan harmonis sehingga mampu melahirkan kebaikan bagi semua orang. Beliau secara tidak lansung juga memberikan sindiran dengan cara yang lembut kepada salah seorang kandidat gubernur DKI Jakarta yang senantisa bersikap emosional dan mengeluarkan kata-kata yang bersifat makian kepada orang lain. Status ini menunjukkan tentang bagaimana beliau berdakwah dengan term qaulan karimah dengan menggunakan kata-kata yang tidak memojokkan pihak lain yang membuat dirinya merasa seakan terhina.

${ }^{27}$ Sumber Data 39: https://www.twitter.com/BuyaSyaffi/status/. Diakses 05 April 2017 pukul 15.17 
Di dalam proses dakwah menjelang Pilkada DKI Jakarta tahun 2017, juga ditemukan bentuk dakwah dengan metode mujadalah (berdebat) di media sosial Twitter. Di dalam metode dakwah mujadalah (berdebat) akan menyampaikan pendapatnya melalui kolom ciutan/ status yang tersedia di Twitter. Follower akan memberikan respon dan komentar pada layanan reply (balasan) yang berada di bawah kolom status yang diunggah. Meskipun tidak banyak dai/ public figure yang membalasnya, tetapi ada dail public figure yang menanggapi respon tersebut, tetapi seperti yang terjadi di Facebook, kebanyakan komentar tersebut justru malah akan dibalas oleh mad'u yang lain, sehingga sekali lagi yang muncul adalah perdebatan antara mad'u.

Di dalam perdebatan yang terjadi, para dai akan mengunggah status yang nantinya dengan bebas memberikan kesempatan kepada mad'u/ followers untuk memberikan tanggapan masing-masing. Apabila dirasa perlu untuk ditanggapi positif ataupun negetif, dai akan memberikan komentar seperlunya, akan tetapi apabila dirasakan bahwa banyak mad'u yang mampu untuk menganggapinya, maka akan diberikan kebebasan untuk saling berbalas komentar diantara mereka.

Sebagai contoh metode dakwah mujadalah (berdebat) di Twitter dapat dilihat pada gambar berikut:

Gambar. 50

Contoh metode dakwah mujadalah (berdebat)

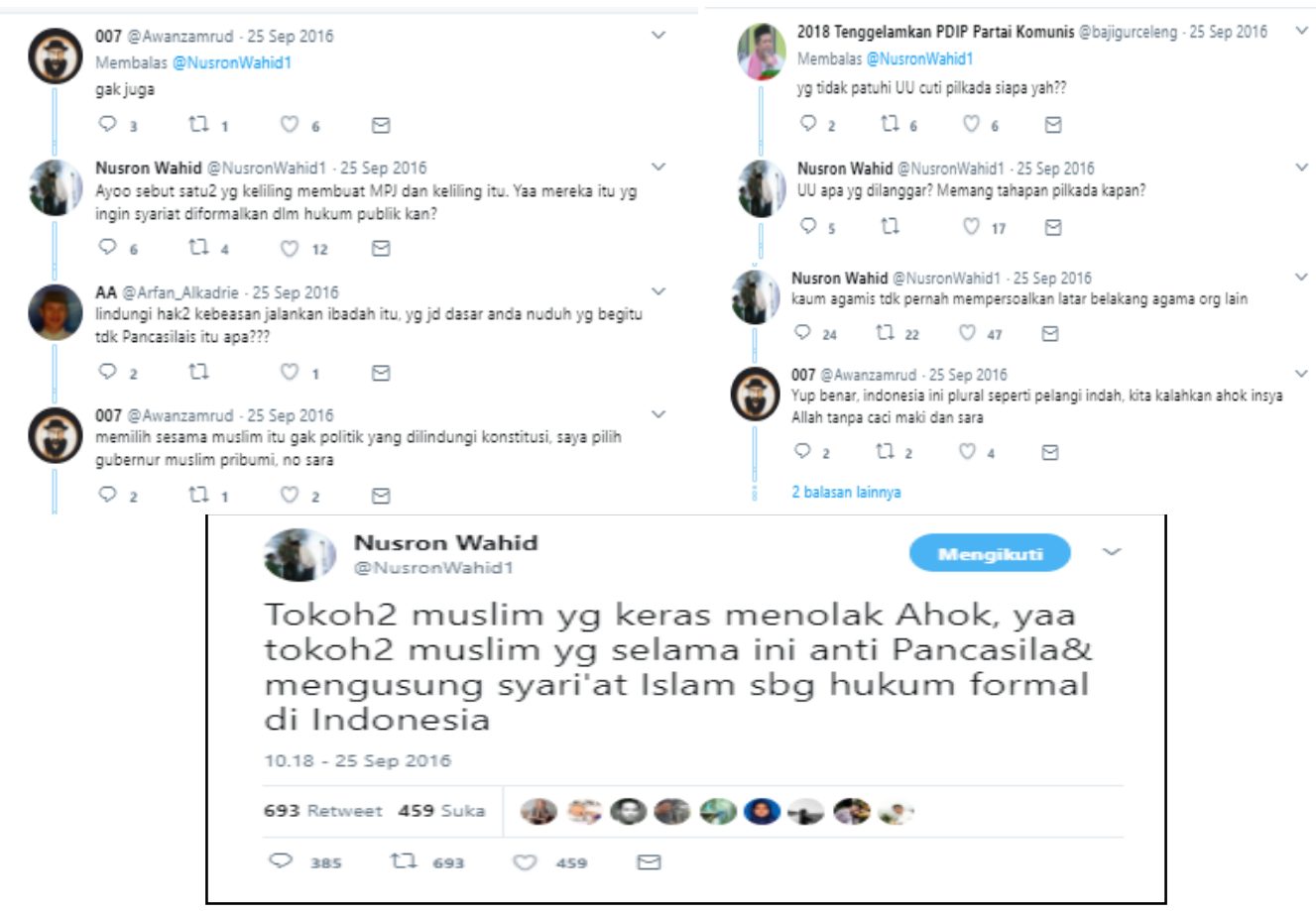

Sumber: Status (tweet) dari Nusron Wahid dan komentar follower tentang politik di Pilkada DKI Jakarta ${ }^{28}$

${ }^{28}$ Sumber Data 40: https://www.twitter.com/NusronWahidl/status/. Diakses 01 Februari 2018 pukul 15.22 
Di dalam status diunggah oleh dai sekaligus tokoh politik Nusron Wahid pada tanggal 26 September 2016, terdapat kritik kepada tokoh-tokoh muslim yang menolak calon gubernur DKI Jakarta yang beragama non-muslim. Pernyataan Nusron Wahid dalam statusnya ini terkesan mencurigai bahwa para tokoh-tokoh muslim tersebut pada dasarnya adalah mereka yang tidak sependapat dengan demokrasi dan Pancasila. Status menimbulkan respon dari pengguna lain sehingga menimbulkan perdebatan. Dakwah mujadalah (berdebat) terlihat pada saat Nusron Wahid merespon komentar beberapa akun follower yang cenderung memberikan kritik terhadap status yang diunggah tersebut. Pada contoh pertama Nusron Wahid mengomentari pendapat dari akun bernama@Awanzamrud yang menolak pernyataannya dengan balasan berupa penyampaian bukti yang menujukkan bahwa tokoh-tokoh muslim tersebut adalah orang-orang yang ingin agar syariah Islam ditegakkan. Contoh kedua Nusron Wahid mengomentari akun @bajigurceleng yang mempertanyakan tentang mekanisme UU Pilkada dan dibalas dengan mempertanyakan kembali tentang tahapan waktu Pilkada DKI Jakarta. Di komentar berikutnya para khalayak yang lebih cenderung melakukan perdebatan dalam menanggapi unggahan status tersebut.

Metode dakwah qudwah hasanah (keteladan) yang disandarkan pada sikap seorang dai dalam kehidupan sehari-hari juga dapat ditemukan di media sosial Twitter menjelang Pilkada DKI Jakarta tahun 2017. Hal ini merujuk kepada bagaimana sikap para dai yang berdakwah di Twiiter dapat selaras dengan perbuatan yang dilakukan dalam relaitas kehidupannya di masyarakat, utamanya yang dilakukan selama masa PilkadaDKI Jakarta. Tujuannya adalah untuk menarik simpati dari mad'u yang selama ini mengkuti dakwah-dakwahnya di media sosial.

Sebagai contoh metode qudwah hasanah (keteladan) yang dapat dilihat pada gambar berikut:

\section{Gambar. 51}

\section{Contoh metode dakwah qudwah hasanah (keteladan)}

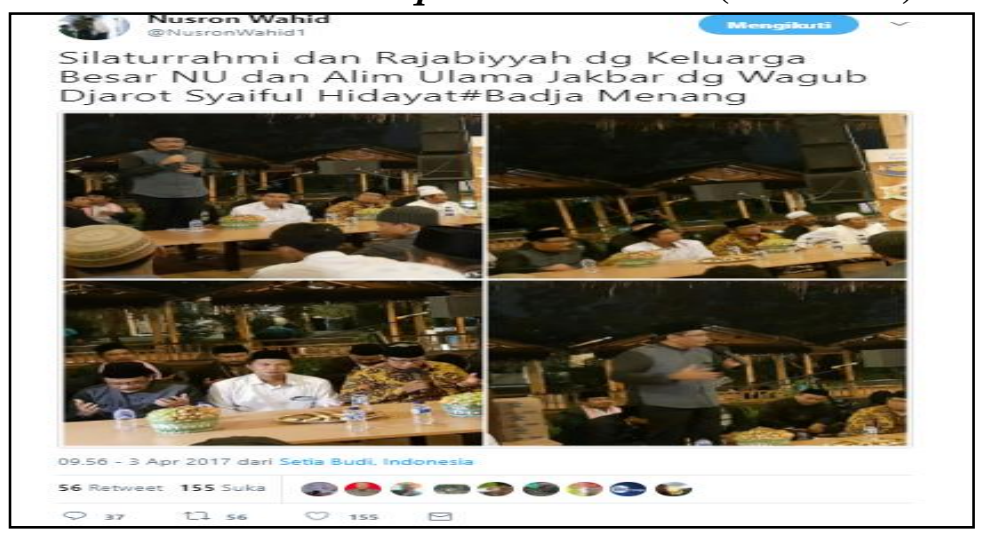

Sumber: Status (tweet) dan gambar yang diunggah oleh Nusron Wahid tentang silaturahmi yang dilakukan oleh calon wakil gubernur DKI Jakarta ${ }^{29}$

${ }^{29}$ Sumber Data 41: https://www.twitter.com/NusronWahidl/status/. Diakses 1 Februari 2018 pukul 16.47 
Di dalam ungahan status dan gambar yang dibagikan oleh Nusron Wahid pada tanggal 3 April 2017, memperlihatkan tentang aktifitasnya mendampingi salah satu calon wakil gubernur DKI Jakarta dalam kunjungan rangka kunjungan silaturahmi dengan tokoh agama dan ulama dari organisasi Nahdatul Ulama (NU) di wilayah Jakarta Barat. Metode qudwah hasanah (keteladan) ini dilakukan bertujuan untuk memperlihatkan kepada mad'u tentang keteladanan dirinya dan calon wakil gubernur DKI Jakarta, Djarot Saiful Hidayat yang senantiasa tetap menunjukkan sikap seorang calon pemimpin muslim yang menghormati para tokoh agama dan ulama. Di samping itu, keteladanan ini berusaha untuk menepis isu-isu negatif terkait tentang calon pemimpin yang tidak pro terhadap para tokoh agama Islam dan ulama.

Contoh lain metode dakwah qudwah hasanah (keteladan) yang ditunjukan oleh dai yang aktif di media sosial Twitter dapat dilihat dari gambar berikut:

Gambar. 52

\section{Contoh metode dakwah qudwah hasanah (keteladan) lainnya}

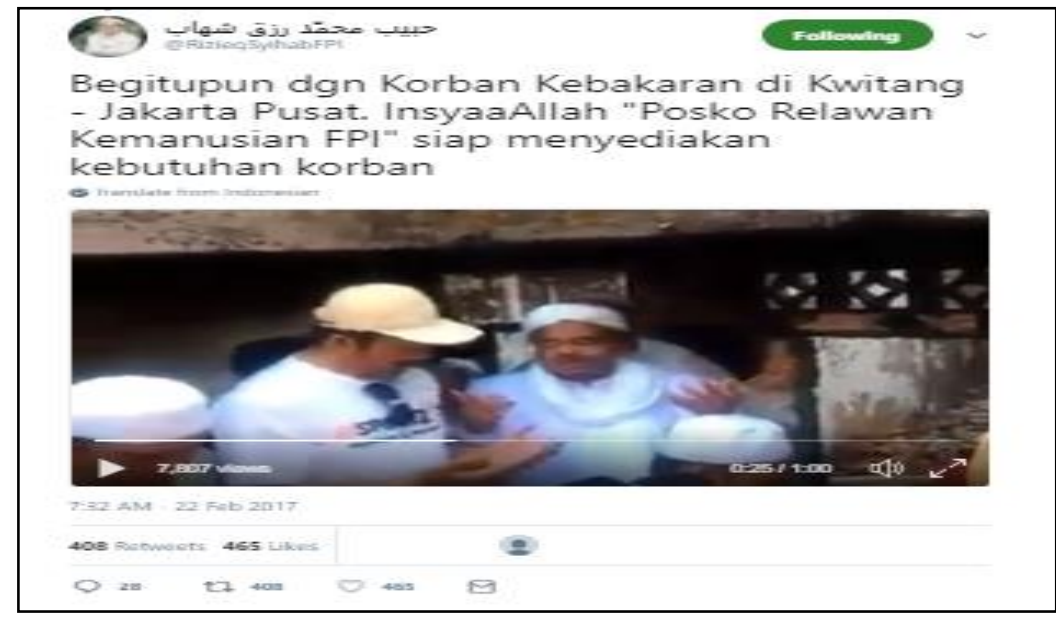

Sumber: Status (tweet) dan video yang diunggah oleh Habib Rizieq Syihab pada masa-masa Pilkada DKI Jakarta ${ }^{30}$

Di dalam status dan video yang diunggah oleh Habib Rizieq Syihab pada tanggal 22 Februari 2017 menunjukkan salah satu contoh metode dakwah qudwah hasanah (keteladan). Di dalam video yang berdurasi 1 menit ini, beliau bersama dengan anggota dari Front Pembela Islam (FPI) melakukan kunjungan, memberikan bantuan dan mendoakan para korban kebaran di wilayah Jakarta Pusat. Hal ini dilakukan untuk menepis isu-isu intoleran yang ditujukan kepada beliau dan orgainisasinya terkait aksi-aksi demontrasi yang dilakukan selama masa menjelang Pilkada DKI Jakarta. Video ini diunggah untuk memperlihatkan kepada mad'ul follower yang ada di Twitter bahwa isu tersebut tidak benar dan mereka adalah ormas yang peduli terhadap sesama.

${ }^{30}$ Sumber Data 42: https://www.twitter.com/RizieqSyihabFPI/status/. Diakses 1 Februari 2018 pukul 16.47 
Oleh karena itu, berdasarkan pada contoh-contoh metode dakwah yang dilakukan oleh para dai dan public figure di media sosial Twitter, maka dapat disimpulkan bahwa Twitter dapat menjadi alternatif dalam mentransformasikan metode-metode dakwah yang ada di masyarakat.

\section{Bentuk Dakwah}

Bentuk dakwah sebagai cara untuk mengajak orang lain dalam melakukan perbuatan amar makruf nahi mungkar yang digunakan oleh para dai untuk mempermudah proses berdakwa. Di media sosial Twitter, bentuk ajakan yang sering digunakan oleh para dai dalam berdakwah juga dapat ditemukan dalam tiga bentuk yaitu: da'wah bil lisan (media lisan), da'wah bil qalam (media tulisan), da'wah bil hal (media perbuatan).

\section{a. Da'wah bil lisan}

Bentuk da'wah bil lisan (media lisan) di media sosial Twitter, terkait interaksi antara dai dengan mad'u yang menyampaikan pesan-pesan dakwah terkait dengan Pilkada DKI Jakarta tahun 2017 dikemas dalam bentuk video rekaman dari seorang dai yang berdakwah lalu menggunggah video tersebut di akun Twitter miliknya dan memberikan kesempatan kepada mad'u/ follower (khalayak) untuk memberikan komentar.

Sebuah contoh $d a^{\text {'wah }}$ bil lisan yang dilakukan oleh seorang dai di Twitter dapat dilihat pada capture gambar video berikut ini:

\section{Gambar. 53}

\section{Contoh metode $d a^{6}$ wah bil lisan}

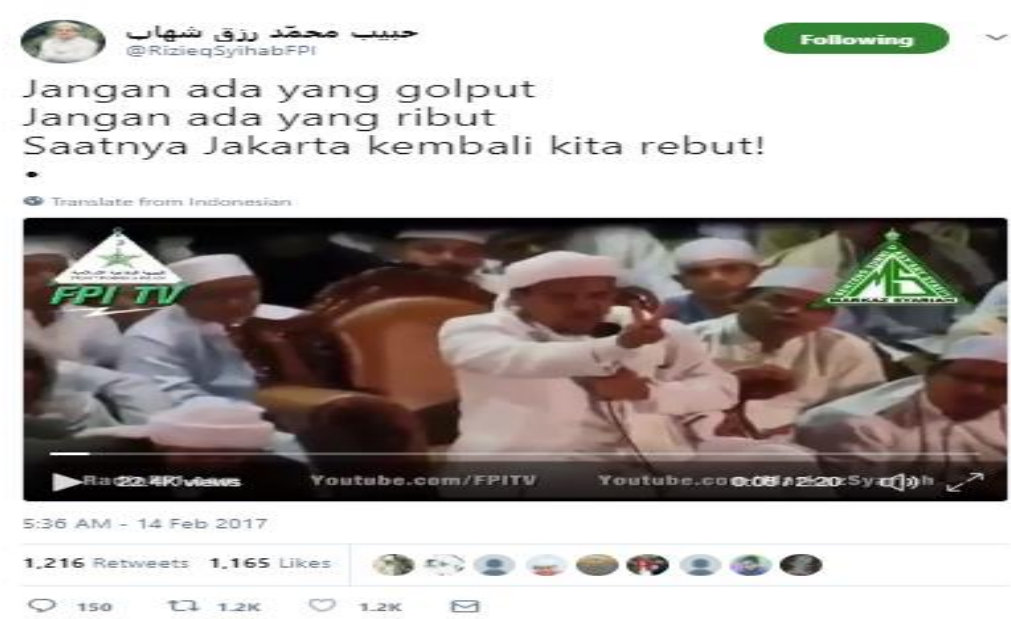

Sumber: Video yang diunggah oleh Habib Rizieq Syihab menjelang pemilihan gubernur dan wakil DKI Jakarta tahun $2017 .^{31}$

${ }^{31}$ Sumber Data 43: https://www.twitter.com/RizieqSyihabFPI/status/. Diakses 7 Februari 2018 pukul 17.21 
Video berdurasi 2 menit 22 detik yang diunggah di Twitter oleh Habib Rizieq Syihab pada tanggal 14 Februari 2017, atau tepatnya sehari sebelum pemilihan gubernur dan wakil DKI Jakarta tahun 2017, beisi tentang ajakan dan himbauan kepada seluruh umat muslim yang ada di DKI Jakarta untuk memilih salah satu dari dua calon gubernur mulim yang ada yaitu Anies Baswedan dan Agus Harimurti Yudhoyono. Di samping itu, beliau juga menganjurkan untuk tidak saling menjatuhkan dan menghina diantara kedua pendukung kedua calon tersebut, agar calon gubernur yang non-muslim dapat dikalahkan sehingga Jakarta dapat direbut kembali oleh umat Islam. Video ini dapat dikategorikan sebagai sebuah bentuk $d a$ 'wah bil lisan yang dilakukan oleh dai di media sosial karena dalam proses dakwahnya, pesan dakwah tersebut disampaikan secara lisan kepada mad'u. Selanjutnya para mad'u/ follower akan memberikan komentar terhadap da'wah bil lisan sebagai berikut:

\section{Gambar. 54 \\ Contoh komentar follower terhadap da'wah bil lisan}
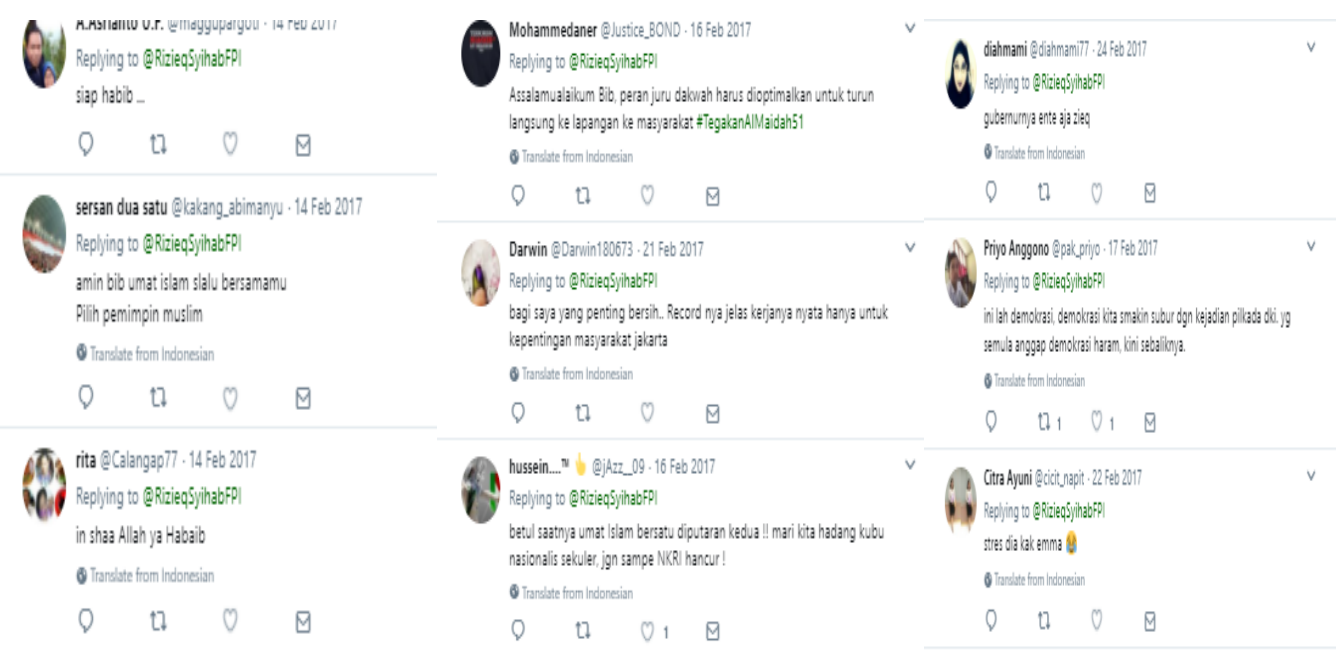

Sumber: Komentar follower terhadap video yang diunggah oleh Habib Rizieq Syihab menjelang pemilihan gubernur dan wakil DKI Jakarta tahun $2017 .^{32}$

Komentar-komentar yang disampaikan oleh mad'u mengambarkan tentang efektifitas da'wah bil lisan dalam menanggapi pesan dakwah yang ditonton melalui video tersebut. Perbedaan dekoding pesan yang diterima setiap mad'u akan berdampak pada lahirnya bentuk interpertasi pesan yang juga berbeda. Pro dan kontra akan mewarni bentuk komentar yang disampaikan. Ada mad'u yang menyatakan kesiapan dan setuju untuk mengikuti ajakan tersebut, ada yang mempertanyakan tentang komitmen Habib Rizieq Syihab yang awalnya menolak demokrasi lalu berbalik terjun untuk hal-hal yang sifatnya politis, adan ada yang dengan tegas menyatakan Habib Rizieq Syihab sedang mengalami gangguan kejiwaan (stress) karena Pilkada DKI Jakarta.

${ }^{32}$ Sumber Data 44: https://www.twitter.com/RizieqSyihabFPI/status/. Diakses 7 Februari 2018 pukul 17.21 
Selain dari unggahan lansung video singkat di Twitter ${ }_{s}$ ada juga dai yang membagikan link video di status Twitter miliknya yang telah di unggah di media sosial YouTube. Hal ini disebabkan karena durasi video tersebut cukup panjang, sedangkan untuk batas durasi maksimal video yang dapat dimuat di Twitter hanya 6-7 menit, sehingga perlu menggunakan media yang lain.

Contoh selanjutnya dari bentuk $d a$ 'wah bil lisan yang seperti itu dapat dilihat dari video dakwah yang diunggah oleh KH. Said Aqil Siroj yang masih berhubungan dengan Pilkada DKI Jakarta tahun 2017.

\section{Gambar. 55 \\ Contoh metode $d a^{6}$ wah bil lisan lainnya}

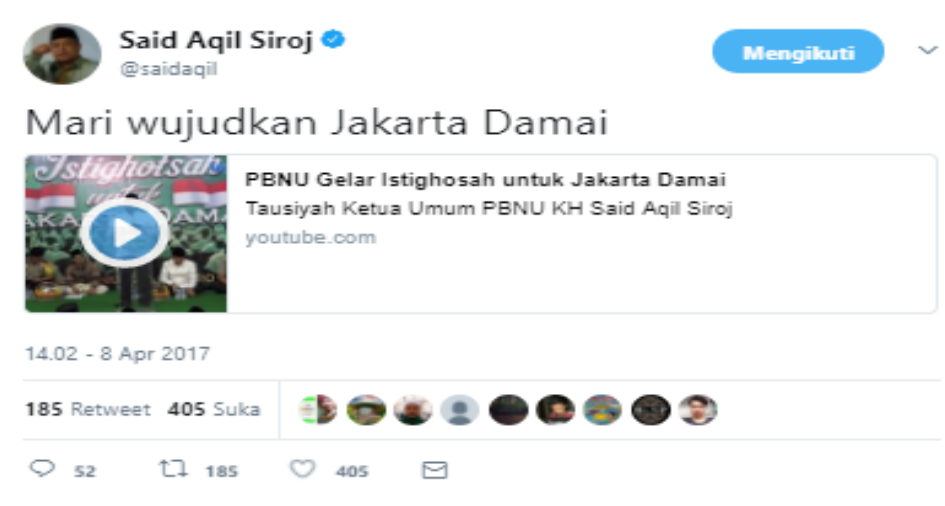

Sumber: Link video yang diunggah oleh KH. Said Aqil Siroj dalam statusnya di

Twitter menjelang pemilihan gubernur dan wakil DKI Jakarta tahun $2017 .^{33}$

Video berdurasi 36 menit 6 detik yang link videonya diunggah di Twitter oleh KH. Said Aqil Siroj pada tanggal 8 April 2017, atau tepatnya menjelang pemilihan putaran kedua gubernur dan wakil DKI Jakarta. Dakwah yang diadakan oleh PBNU dengan mengambil judul "Istighosah untuk Jakarta Damai" memperlihatkan KH. Said Aqil Siroj sedang memberikan ceramah tentang ajaran agama Islam yang senantiasa mengajarkan tentang kedamaian dalam mengajak orang lain, termasuk ajakan untuk memilih pemimpin di Pilkada DKI Jakarta nantinya. Beliau yang juga menjabat sebagai Ketua Umum PBNU menghimbau bahwa setiap simapatisan calon gubernur, baik dari kubu Basuki Tjahaja Purnama maupun dari kubu Anies Baswedan untuk senantiasa menjaga silaturahmi dan perdamaian serta tidak saling melontarkan ujaran kebencian satu sama lain. Da'wah bil lisan cenderung terlihat sebagai antitesa dari dakwah-dakwah yang dilakukan oleh dai lainnya yang terkesan keras dalam menolak dan mengkampanyekan larangan bagi umat muslim untuk memilih pemimpin non muslim di DKI Jakarta.

Da'wah bil lisan yang disampaikan oleh KH. Said Aqil Siroj terkesan menenangkan, akan tetapi tetap saja menimbulkan pro dan kontra dari para pukul 14.47

${ }^{33}$ Sumber Data 45: https://www.twitter.com/saidaqil/status/. Diakses 1 Februari 2018 
mad'u/ follower yang melihatnya. Hal ini sekali lagi disebabkan karena adanya pro dan kontra yang lahir sebagai hasil dari represantasi setiap orang yang melihat dakwah tersebut. Contoh komentar yang pro dan kontra dapat dilihat dari gambar berikut:

\section{Gambar. 56}

\section{Contoh komentar follower terhadap da'wah bil lisan}
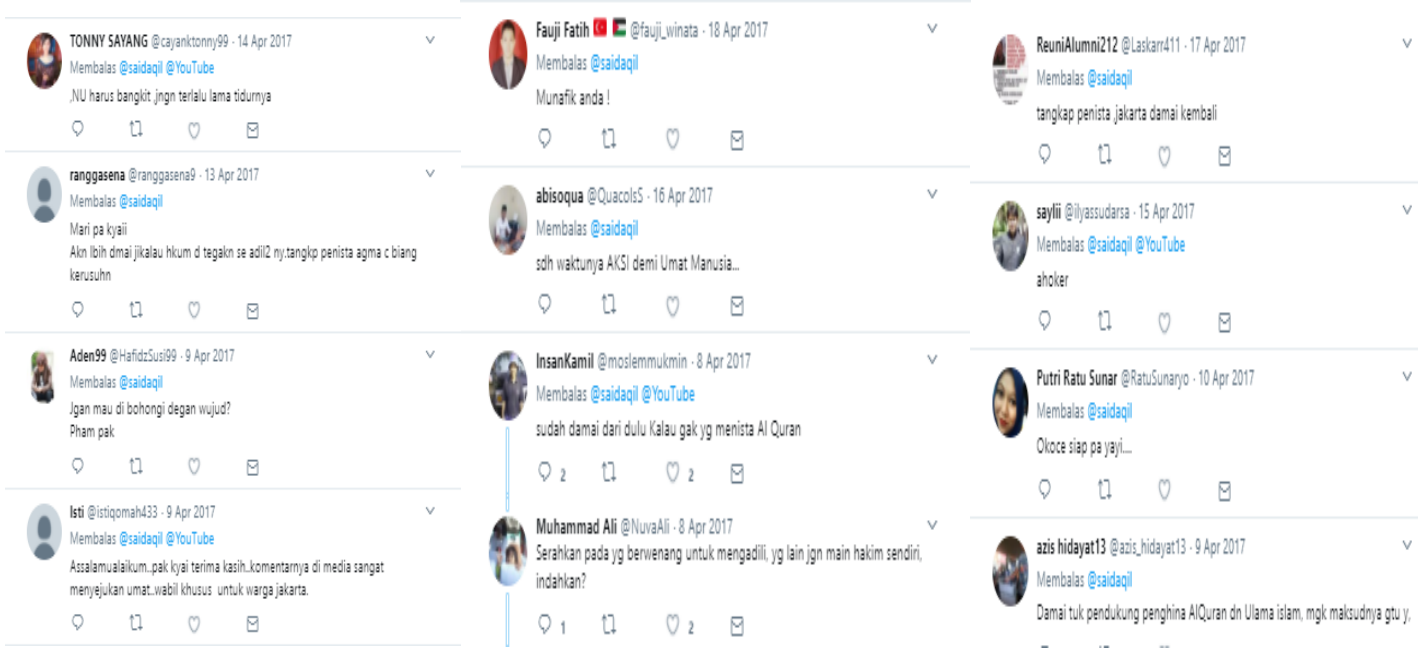

Sumber: Komentar follower terhadap video yang diunggah oleh KH. Said Aqil Siroj menjelang pemilihan gubernur dan wakil DKI Jakarta tahun $2017 .^{34}$

Berdasarkan komentar-komentar yang menjadi hasil dari respon mad'u yang telah menyaksikan video yang diunggah di akun KH. Said Aqil Siroj menunjukkan bahwa siapapun orangnya, baik itu seorang dai terkenal yang juga menjabat sebagai ketua umum organisasi Islam besar di Indonesia, tidak akan pernah terhindar dari pro dan kontra. Ini terbukti karena beberapa komentar terkesan meragukan independensi dan komitmen dari KH. Said Aqil Siroj. Ada yang menanggapi bahwa yang disampaikan oleh beliau hanya terkesan sebagai bentuk dukungan terhadap kandidat non-muslim, ada yang mengatakan bahwa beliau munafik, ada yang mengatakan bahwa perdamaian akan terwujud apabila Basuki Tjahaja Purnama (Ahok) segera ditangkap, Akan tetapi ada juga yang pro, yang mengatakan bahwa da'wah bil lisan oleh beliau membawa kesejukan dan pesan perdamaian.

Berdasarkan pada contoh-contoh da'wah bil qalam yang terdapat di Twitter menunjukkan bahwa adanya transformasi media penyampai pesan dalam bentuk lisan yang sebelumnya dilakukan dengan interaksi tatap muka lansung antara dai dengan mad'u, kini telah dimudahkan dengan adanya Twitter sebagai media perantara pesan dakwah.

\footnotetext{
${ }^{34}$ Sumber Data 46: https://www.twitter.com/saidaqil/status/. Diakses 1 Februari 2018 pukul 14.51
} 


\section{b. Da'wah bil qalam}

Bentuk dakwah di Twitter dalam moment Pilkada DKI Jakarta tahun 2017 akan lebih banyak ditemuka dalam bentuk dakwah tulisan (da'wah bil qalam). Hal ini disebabkan karena kecenderungan para dai merasa bahwa bentuk dakwah seperti ini lebih cocok dengan fungsi Twitter yaitu berbagi berita dan komentar (sharing news and commentary) yang cenderung lebih mudah untuk dipahami oleh mad'u/ followers.

Transformasi da'wah bil qalam yang terjadi di media sosial Twittetr, pada umumnya tidak jauh berbeda dengan bentuk da'wah bil qalam sebagaimana yang umumnya dilakukan dengan menggunakan media cetak atau pun di media sosial lainya, seperti Facebook. Pemahaman pesan da'wah bil qalam yang diterima oleh mad'u biasanya lebih ditentukan oleh pemahamanan dan keterampilan mad'u untuk menginterpretasikan pesan dakwah yang tertulis dan kecenderungannya terhadap dai yang menyampaikan dakwah tersebut.

Contoh metode da'wah bil qalam yang dapat ditemukan di media sosial Twitter dapat dilihat pada gambar berikut:

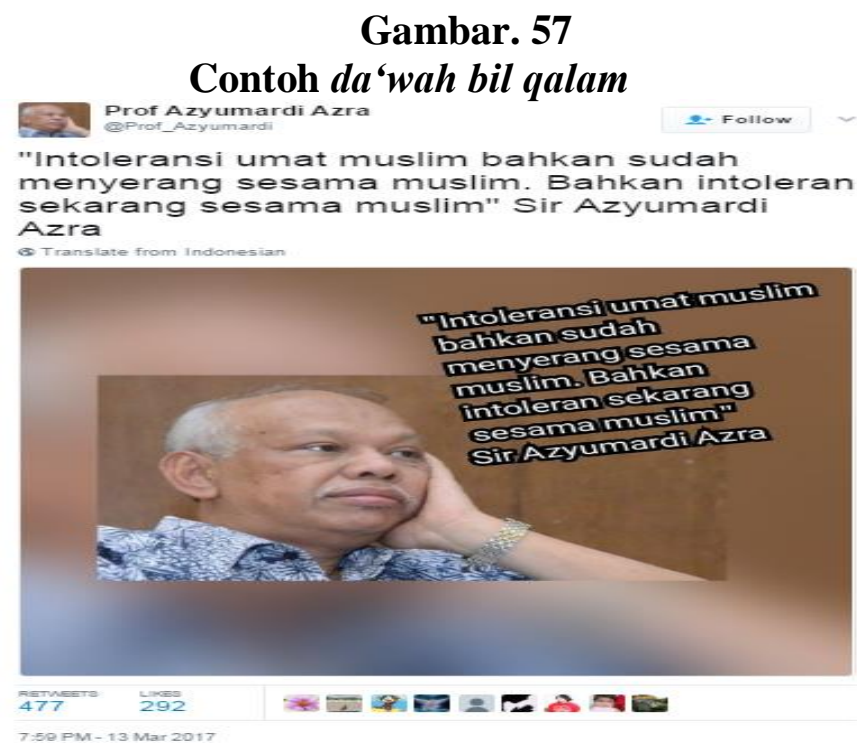

Sumber: Status/ ciutan ( $d a$ 'wah bil qalam) yang diunggah oleh Prof. Azyumardi Azra. ${ }^{35}$

Status tulisan yang diunggah oleh seorang dai sekaligus akademisi muslim Prof. Azyumardi Azra pada tanggal 13 Maret 2017, tampak sedang menyinggung maraknya isu intoleransi yang terjadi, yang tidak hanya antara umat muslim dengan non-muslim, akan tetapi juga marak terjadi antara sesama umat muslim di masa-masa Pilkada DKI Jakarta. Status ini merupakan interpertasi pandangan dari beliau melihat kondisi sosial yang terjadi antara pendukung dan simpatisan calon

${ }^{35}$ Sumber Data 47: https://www.twitter.com/Prof_Azyumardi/status/. Diakses 5 April 2017 pukul 12.57 
gubernur DKI Jakarta. Perbedaan pilihan diindikasikan menjadi sebab lahirnya tindakan saling menghujat dan mencaci maki satu sama lain. Oleh karena itu melalui da'wah bil qalam ini, Prof. Azyumardi Azra secara tidak lansung memperingatkan kepada sesama muslim untuk tetap menjaga silaturahmi, meskipun berbeda pandangan dalam memilih calon pemimpin di DKI Jakarta nantinya.

Da'wah bil qalam yang dilakukan oleh Prof. Azyumardi Azra secara lansung mendapatkan beragam respon dari mad'u yang telah membacanya.

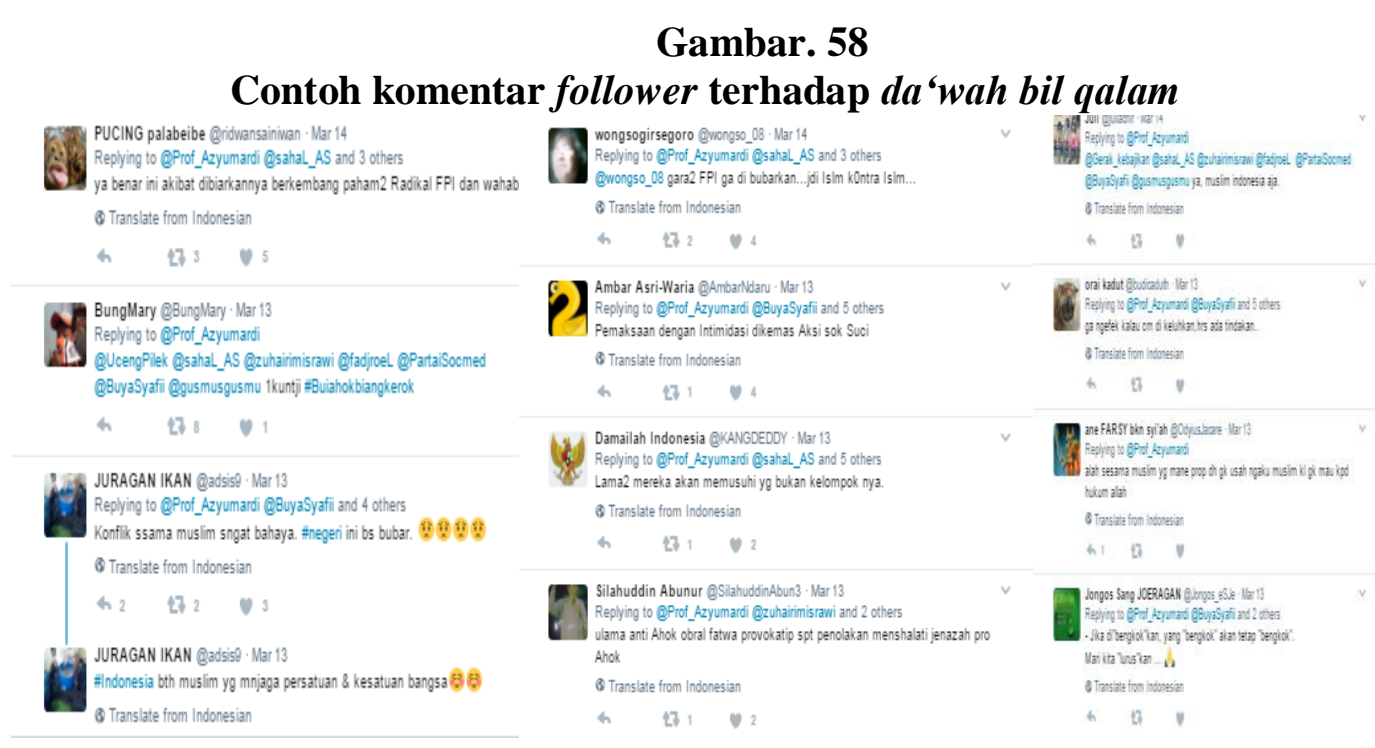

Sumber: Komentar followers terhadapa status/ ciutan ( $d a$ 'wah bil qalam) yang diunggah oleh Prof. Azyumardi Azra. ${ }^{36}$

Para mad'u/ followers mendapatkan kebebasan untuk mendekoding pesan dakwah yang disampaikan oleh Prof. Azyumardi Azra berdasarkan atas interpretasinya masing-masing. Dalam komentar ini ada yang mendukung dan menyatakan kesepemahamannya dengan status yang di unggah oleh Prof. Azyumardi Azra. Ada yang menegaskan bahwa yang sepatutnya disalahkan adalah pemeritah yang tidak mampu mengambil sikap, dan bahkan ada yang menganggap bahwa beliau berkata demikian karena cenderung terindikasi berpihak kepada liberalisme, dan tidak kepada ajaran Islam yang sebenarnya.

Contoh metode $d a$ 'wah bil qalam lainnya yang dijadikan sebagai alternatif dalam menyampaikan pesan dakwah di media sosial Twitter pada gambar berikut:

${ }^{36}$ Sumber Data 48: https://www.twitter.com/Prof_Azyumardi/status/. Diakses 5 April 2017 pukul 13.05 


\section{Gambar. 59}

\section{Contoh da'wah bil qalam Ulil Abshar Abdallah}

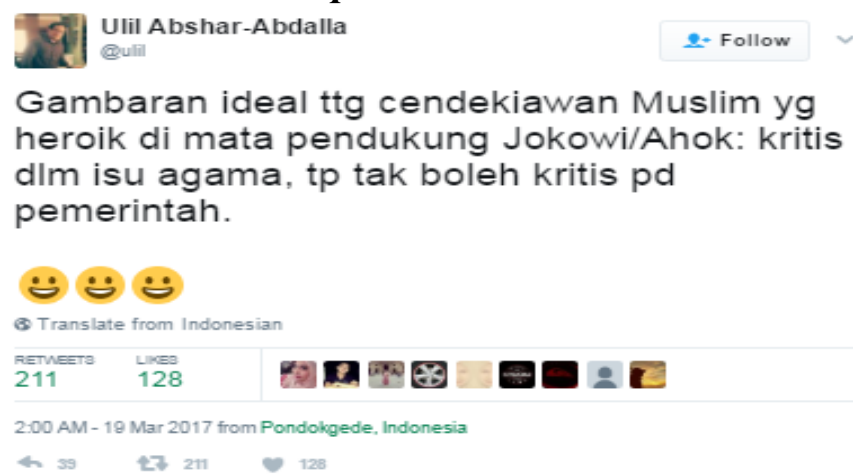

Sumber: Status/ ciutan ( $d a$ 'wah bil qalam) yang diunggah oleh Ulil Abshar Abdallah. ${ }^{37}$

Status yang diunggah oleh Ulil Abshar Abdallah seorang dai dan akademisi pada tanggal 19 Maret 2017, menyampaikan kritik terhadap para pendukung Presiden Jokowi yang juga disinyalir mendukung calon gubernur DKI Jakarta, Basuki Tjahaja Purnama (Ahok) yang terkesan menganggap bahwa para ulama, dai dan cendikiawan muslim yang kritis terhadap pemerintah, bukanlah sosok yang pantut untuk dijadikan sebagai teladan. Kritik ini lahir, karena para pendukung dan simpatisan dari calon gubernur DKI Jakarta, Basuki Tjahaja Purnama (Ahok) selalu mengatakan bahwa orang-orang yang kritis terhadap pemerintah, adalah orang yang tidak menghargai perbedaan serta tidak menginginkan demokrasi. Da'wah bil qalam yang disampaikan oleh Ulil Abshar Abdallah, selain untuk mengkritik para pendukung fanatik tersebut, di sisi lain juga mencoba untuk merekontruksi pemikiran mereka agar lebih terbuka terhadap gerakan-gerakan umat Islam yang mengkritik pemerintahan selama Pilkada DKI Jakarta.

Da 'wah bil qalam yang dilakukan oleh Ulil Abshar Abdallah, sekali lagi tidak dapat terlepas dalam melahirkan bentuk pro dan kontra mad'u/ followers terhadap pesan tersebut. Ada mad'u yang mengkritik bahwa pesan dakwah yang disampaikan oleh beliau lebih cenderung kepada sikap politiknya, bukan murni sebagai ajakan kepada umat muslim. Ada yang mempertanyakan apakah dakwah ini merupakan kritik atau lebih cenderung kepada ujaran kebenciannya terhadap Jokowi dan Ahok, ada yang mengingatkan bahwa beliau tidak usah ikut terlibat dalam prasangka buruk terhadap pemerintah dan ada juga yang mendukung bahwa gerakan dakwah seperti ini harus terus dilakukan agar dapat sampai kepada pemerintah. Munculnya beragam respon dari mad'u sebagai wujud dari perbedaan persepsi dan pemahaman setiap orang terhadap menanggapi pesan dakwah yang diterimanya. Beberapa contoh komentar yang telah dijelaskan dapat dilihat pada gambar berikut:

\footnotetext{
${ }^{37}$ Sumber Data 49: https://www.twitter.com/ulil/status/. Diakses 5 April 2017 pukul 13.49
} 


\section{Gambar. 60}

\section{Contoh komentar follower terhadap da'wah bil qalam Ulil Abshar Abdallah}
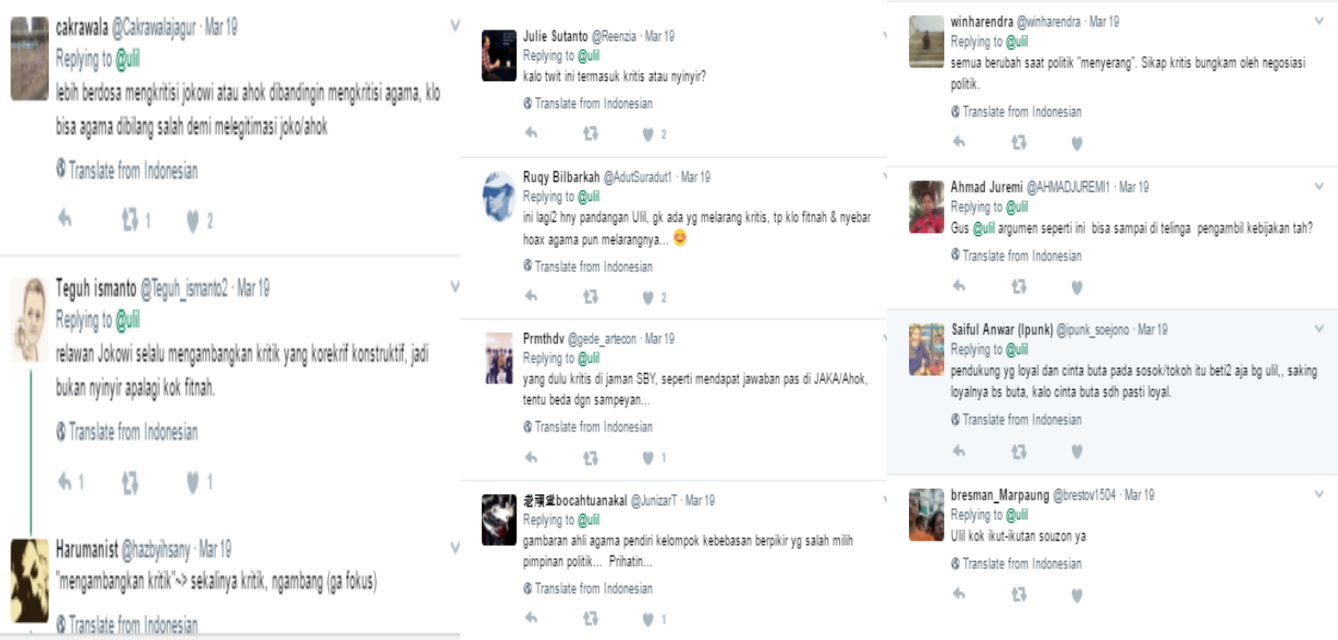

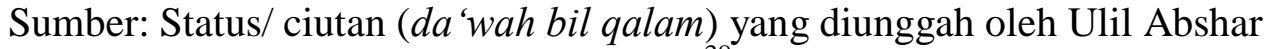
Abdallah. ${ }^{38}$

Sengkarut kelindang perang dakwah di media sosial Twitter menjadi semakin rumit akibat keberpihakan dari para dai ataupun public figure terhadap salah satu calon gubernur DKI Jakarta. Akibatnya, justru berdampak pada maraknya kampanye gelap (black campaign) yang menyerang kandindat lainnya. Terkadang status da'wah bil qalam yang mengandung unsur kampanye gelap (black campaign) akan memberikan gambaran tentang kandidat yang diserang melalui perbandingan sebelum dan pada saat calon tersebut maju di dalam Pilkada DKI Jakarta. Contoh tersebut dapat dilihat dari $d a$ 'wah bil qalam berikut ini:

Gambar. 61

\section{Contoh da'wah bil qalam Akhmad Sahal}

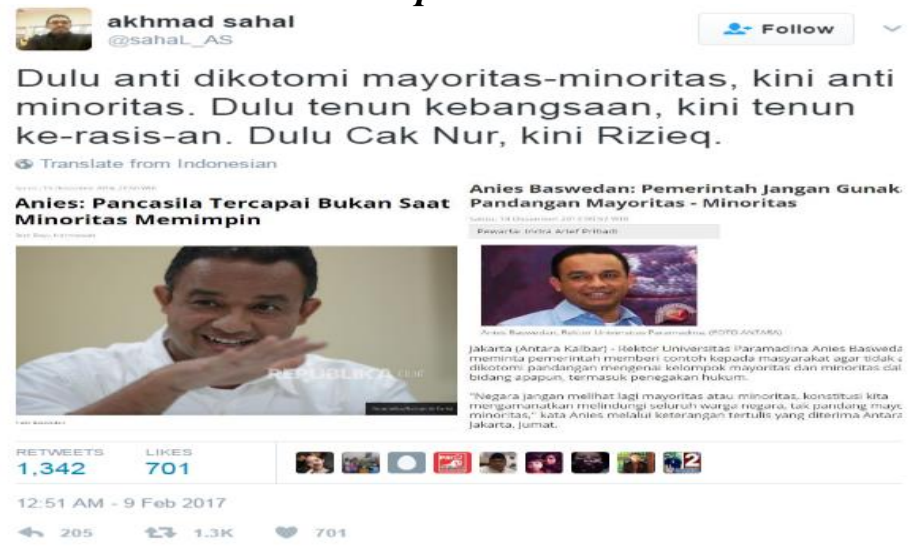

Sumber: Status/ ciutan (da'wah bil qalam) yang diunggah oleh Akhmad Sahal. ${ }^{39}$

\footnotetext{
${ }^{38}$ Sumber Data 50: https://www.twitter.com/ulil/status/. Diakses 5 April 2017 pukul 13.55

${ }^{39}$ Sumber Data 51: https://www.twitter.com/sahal_AS/status/. Diakses 17 Februari 2017 pukul 13.48
} 
Status yang diunggah oleh Akhmad Sahal seorang akademisi dan aktivis Jaringan Islam Liberal (JIL) Indonesia pada tanggal 9 Februari 2017 memuat gambaran komitmen yang tidak jelas yang ditujukkan oleh calon gubernur DKI Jakarta, Anies Baswedan. Di dalam da'wah bil qalam ini, Akhmad Sahal mengunggah potongan headline berita yang menunjukkan tentang dikotomi statement Anies Baswedan dalam menyikapi kelompok minortias dan pemerintah. Di dalam caption gambar headline berita tersebut, tampak bahwa sebelum menjadi calon gubernur, Anies Baswedan mendukung kepemimpinan yang berasal dari minoritas, lalu pada saat beliau mencalonkan diri sebagai gubernur, dukungan tersebut berubah menjadi kritikan terhadap pemerintah yang lebih berpihak kepada kelompok minoritas. Da'wah bil qalam yang mengandung unsur kampanye gelap (black campaign) tergambar dalam status tersebut.

Bentuk da'wah bil qalam yang seperti ini, pada akhirnya kembali melahirkan perdebatan antara mad'u/ followers dalam menyikapi pesan yang disampaikan. Perbedatan tersebut tergambar dalam komentar berikut ini:

Gambar. 62

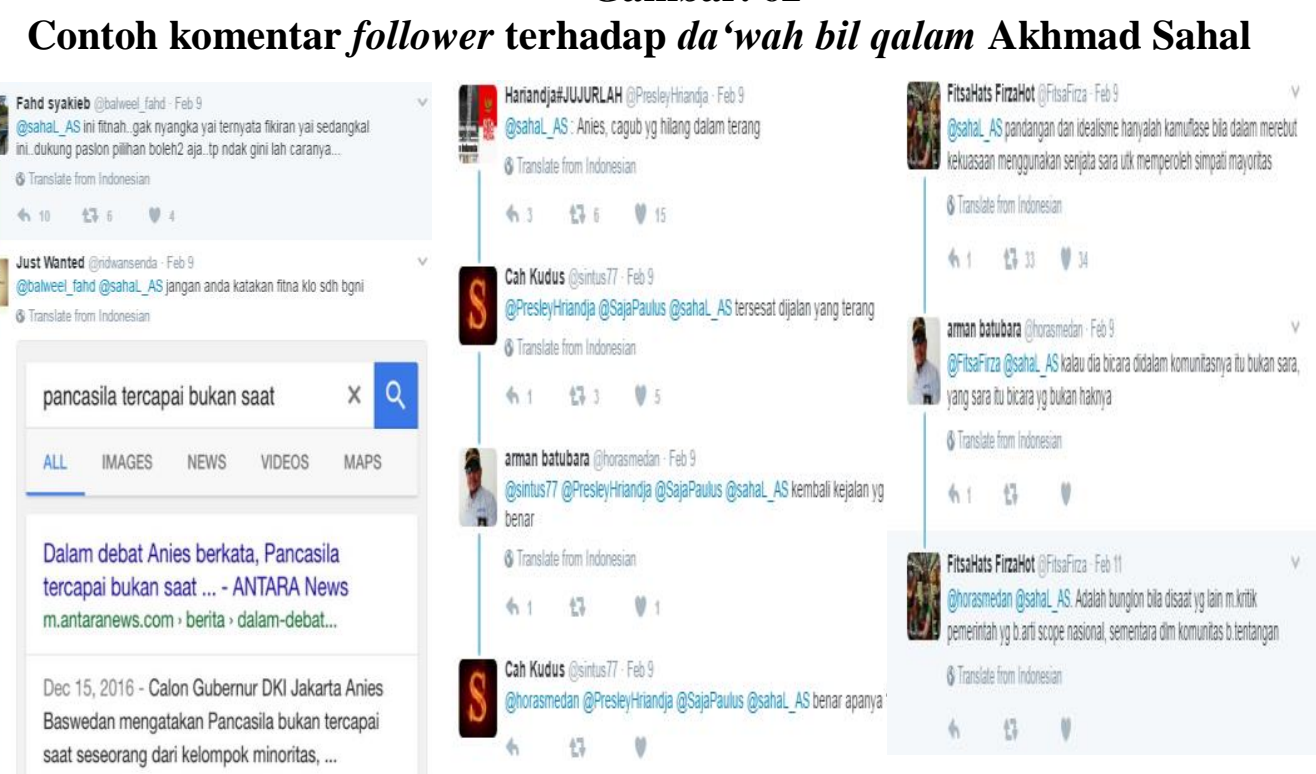

Sumber: Komentar terhadap status/ ciutan ( $d a^{\prime}$ wah bil qalam) yang diunggah oleh Akhmad Sahal. ${ }^{40}$

Setelah melihat dan membaca status yang diunggah oleh Ulil Abshar Abdallah, maka dengan cepat para follower akan memberikan respon dan umpan balik terhadap pesan da'wah bil qalam tersebut. Ada yang menyatakan kekecewaannya terhadap Akhmad Sahal yang selama ini dipandang sebagai seorang cendikiawan muslim, akan tetapi menyebarkan fitnah kepada salah calon

\footnotetext{
${ }^{40}$ Sumber Data 52: https://www.twitter.com/sahal_AS/status/. Diakses 17 Februari 2017 pukul 13.51
} 
gubernur DKI Jakarta, ada yang memberikan konfirmasi bahwa statement yang disampaikan oleh Anies Baswedaan hanya diucapkan ketika berada di dalam kelompoknya, ada yang mengatakan bahwa langkah yang diambil Anies Baswedaan sudah tepat, ada yang setuju dengan pendapat dan berita yang diunggah oleh Akhmad Sahal, dan ada yang dengan tegas menyerang balik Akhmad Sahal dengan ujaran kebencian. Semua komentar tersebut, adalah hak pribadi masing-masing mad'u/ followers berdasarkan pada mindsetnya masingmasing.

Berdasarkan dari beberapa contoh da'wah bil qalam yang telah dipaparkan oleh peneliti menunjukkan bahwa salah satu fungsi lainnya dari media sosial Twitter yaitu mind reading (membaca pikiran) yang memberikan kesempatan bagi pengguna untuk tidak hanya berfokus pada apa yang dipikrikan oleh status yang dibagikan seseorang, akan tetapi juga dapat melihat di kelompok atau golongan mana mereka berada di masyarakat.

\section{c. Da'wah bil hal}

Bentuk dakwah terakhir yang dapat ditemukan di dalam media sosial Twitter yang terintegrasi pada momentum Pilkada DKI Jakarta tahun 2017, adalah bentuk aksi sosial ( $d a$ 'wah bil hal). Para dai dan public figure menerapkan bentuk da'wah bil hal dengan tujuan untuk menarik simpati dan mengajak masyarakat untuk melakukan kegiatan serupa, yang pada umumnya adalah kegiatan-kegiatan sosial masyarakat.

Da 'wah bil hal yang terjadi di Twitte, seperti halnya bentuk da'wah bil hal yang dilakukan di media sosial Facebook mendokumentasikan kegiatan sosial yang merka lakukan dalam bentuk foto atau video yang selanjutnya diunggah oleh dai di akun-akun masing-masing sehingga dapat disaksikan oleh mad'u tentang apa saja aktifitas sosial yang akan atau telah mereka lakukan.

Da'wah bil hal di Twitter selama momentum Pilkada DKI Jakarta tahun 2017, para dai akan mengabarkan aktifitas yang sedang mereka lakukan terkait dengan momentum DKI Jakarta 2017. Di samping itu, da'wah bil hal para dai akan menjadi referensi para mad'u/ followers untuk menyikapi kasus-kasus/ peristiwa yang terjadi menjelang Pilkada DKI Jakarta tahun 2017.

Contoh da'wah bil hal yang dilakukan oleh seorang dai di Twitter dapat dilihat pada capture gambar berikut ini: 
Gambar. 63

Contoh bentuk da'wah bil hal

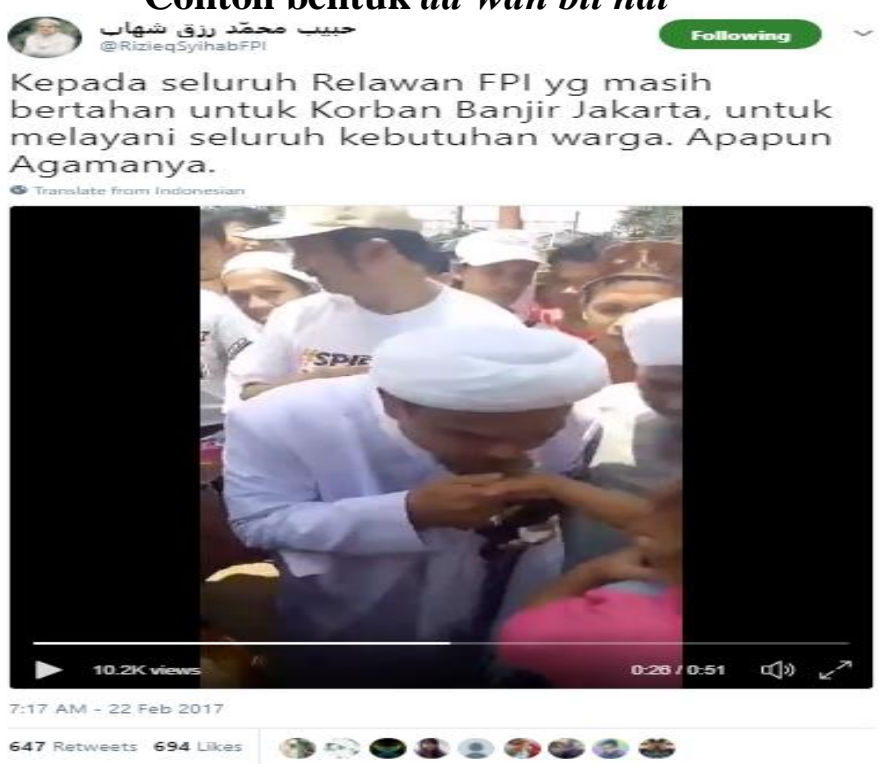

Sumber: Video (da'wah bil hal) yang diunggah oleh Habib Rizieq Syihab pada masa Pilakda DKI Jakarta. ${ }^{41}$

Di dalam video yang diunggah di akun Tiwtter milik Habib Rizieq Syihab pada tanggal 22 Februari 2017 menunjukan salah satu contoh bentuk da wah bil hal yang juga dapat diinternalisasi sebagai sebuah metode dakwah qudwah hasanah (keteladan). Video yang berdurasi 51 detik ini menampilkan sosok Habib Rizieq Syihab bersama istri dan rombongan dari ormas Fron Pembela Islam (FPI) sedang mengunjungi korban banjir di wilayah DKI Jakarta. Dalam video ini tampak beliau sedang berbincang dengan warga korban banjir tentang kesiapannya bersama seluruh anggota FPI untuk membantu menyediakan segala kebutuhan warga, utamanya kebutuhan bagi anak-anak korban banjir tersebut. Hal menarik yang dapat disaksikan dalam video ini, tampak beliau menyalami anak kecil lalu mencium tangan anak tersebut dan mendoakan agar menjadi anak yang saleh. Tergambar bahwa Habib Rizieq Syihab mencoba menarik simpati masyarakat untuk melakukan aksi sosial yang serupa dan berusaha menghilangkan stigma yang berkembang di masyarakat bahwa dirinya serta organisasi yang dipimpinnya adalah organisasi yang ekslusif.

Pada kenyataanya, da'wah bil hal yang dilakukan oleh cukup Habib Rizieq Syihab cukup mempengaruhi para mad'u/ follower yang telah menyaksikan video tersebut. Banyaknya komentar follower yang lebih mengarahkan kepada hal yang positif dan mendukung aksi sosial yang dilakukan oleh beliau. Akan tetapi, ada juga komentar negatif dari followers dalam menanggapi da 'wah bil hal tersebut. Komentar tersebut dapat dilihat pada gambar berikut ini:

${ }^{41}$ Sumber Data 53: https://www.twitter.com/RizieqSyihabFPI/status/. Diakses 1 Februari 2018 pukul 17.01 
Gambar. 64

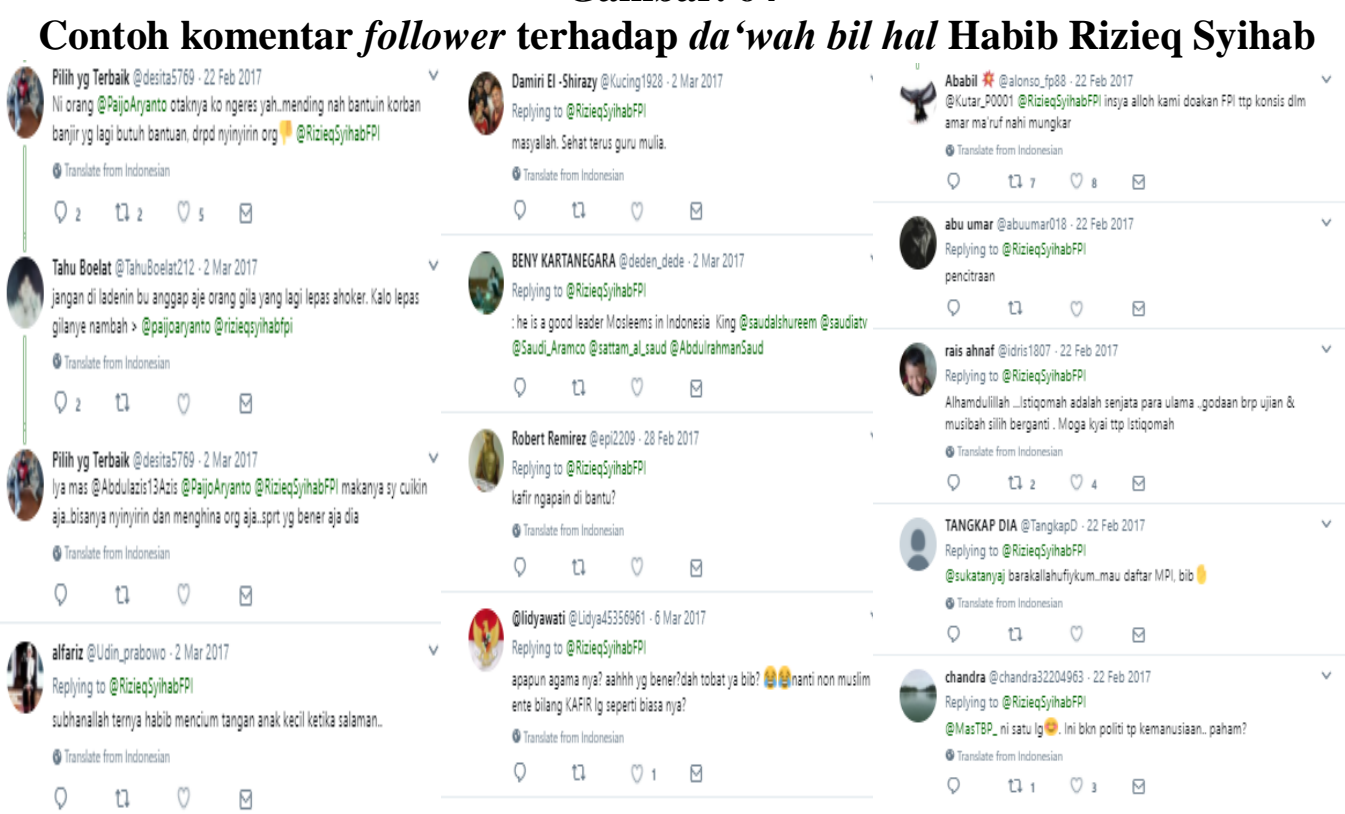

Sumber: Komentar terhadapa video ( $d a$ 'wah bil hal) yang diunggah oleh Habib Rizieq Syihab pada masa Pilakda DKI Jakarta. ${ }^{42}$

Komentar-komentar dari followers yang menanggapi video aksi sosial yang diunggah oleh Habib Rizieq Syihab menunjukkan bahwa pada akhirnya semakin banyak masyarakat yang bersimpati dengan sosok beliau setelah serangkaian aksi bela Islam yang dimotori olehnya. Di samping itu, melalui video ini para masyarakat melihat bahwa apa yang beliau sampaikan sejalan dengan apa yang perbuatan beliau. Ada komentar yang memuji, kerendahan hati Habib Rizieq Syihab yang rela mencium tangan anak kecil dan mendoakannya, ada yang memuji ajakan beliau yang mengajak untuk membantu semua orang tanpa memandang agamanya, dan ada yang mendoakan agar beliau dan organisasinya senatiasa di rahmati oleh Allah swt. Dari sisi yang kontra, komentar yang disampaikan cenderung mengkritik bahwa aksi tersebut hanya pencitraan/ tidak ikhlas karena hanya bertujuan menarik simpati publik.

Selain dalam bentuk video, bentuk da'wah bil hal juga dapat berbentuk gambar/ foto seperti yang sebelumnya telah dijelaskan. Gambar/ foto yang diunggah tetap memperlihatkan contoh aksi sosial yang dilakukan oleh dai atau public figure di masyarakat, yang bertujuan untuk mengajak kepada mad'u untuk melakukan hal yang serupa. Contoh $d a{ }^{\text {'wah }}$ bil hal yang berbentuk unggahan foto dapat dilihat pada gambar berikut:

${ }^{42}$ Sumber Data 54: https://www.twitter.com/RizieqSyihabFPI/status/. Diakses 1 Februari 2018 pukul 17.01 
Gambar. 65

Contoh bentuk da'wah bil hal lainnya

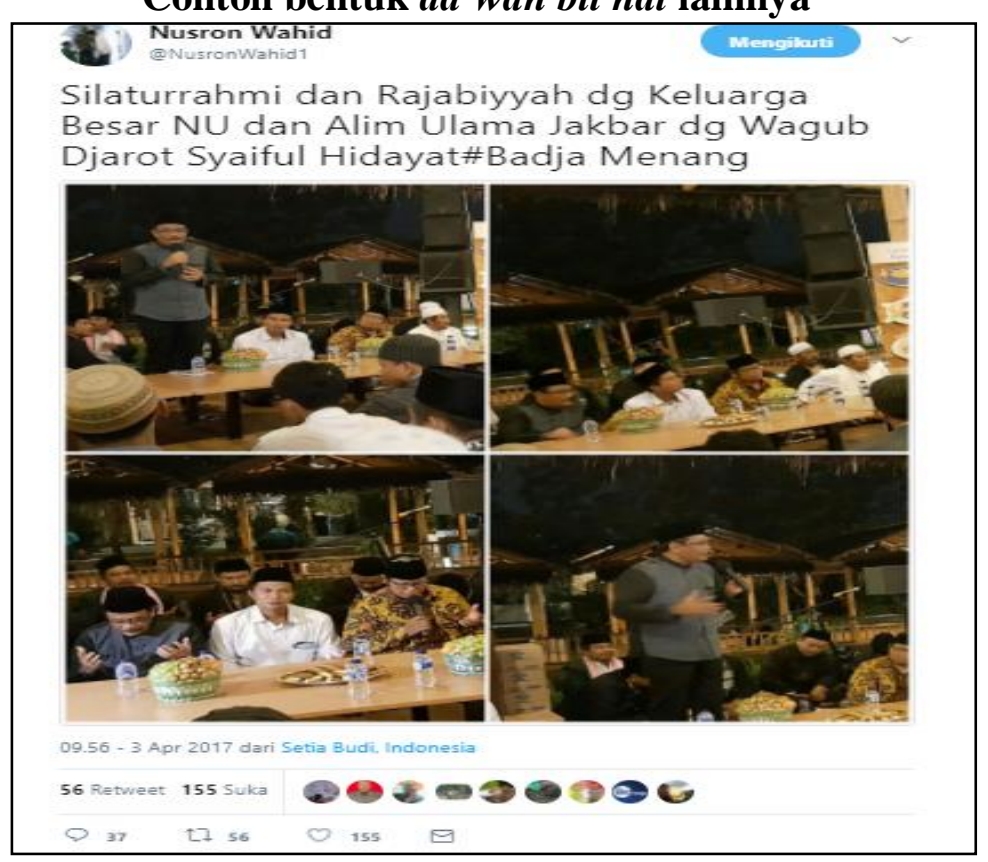

Sumber: Gambar (da'wah bil hal) yang diunggah oleh Nusron Wahid tentang silaturahmi yang dilakukan oleh calon wakil gubernur DKI Jakarta ${ }^{43}$

Seperti contoh bentuk da 'wah bil hal yang sebelumnya dibahas, bahwa bentuk dakwah ini sejalan dengan metode dakwah qudwah hasanah (keteladan) yang dilakukan oleh dai di media sosial Twitter. Hal ini dapat dilihat pada gambar yang diunggah oleh Nusron Wahid pada tanggal 3 April 2017 yang memperlihatkan kampanye yang dilakukan oleh salah satu calon wakil gubernur, Djarot Syaiful Hidayat menjelang putaran kedua Pilkada DKI Jakarta yang lebih memilih silaturahmi dan memperingati Rajabiyyah (peringatan 27 Rajab) bersama dengan tokoh-tokoh dan warga Nahdlatul Ulama di wilayah DKI Jakarta. Di dalam gambar ini memberikan kesan bahwa Djarot Syaiful Hidayat adalah seorang sosok calon pemimpin yang religius dan taat beribadah dalam kesehariannya. Pesan ini mencoba menarik simpati dari umat muslim lainnya untuk memilih calon pemimpin muslim seperti beliau.

Foto yang diunggah tersebut pada akhirnya kembali akan dikomentari oleh para mad'u untuk menggambarkan suasana hati dan persepsi yang mereka dapatkan setelah meliht foto tersebut. Beberapa komentar tersebut adalah sebagai berikut:

${ }^{43}$ Sumber Data 41: https://www.twitter.com/NusronWahidl/status/. Diakses 1 Februari 2018 pukul 16.47 
Gambar. 66

Contoh komentar follower terhadap da'wah bil hal Nusron Wahid
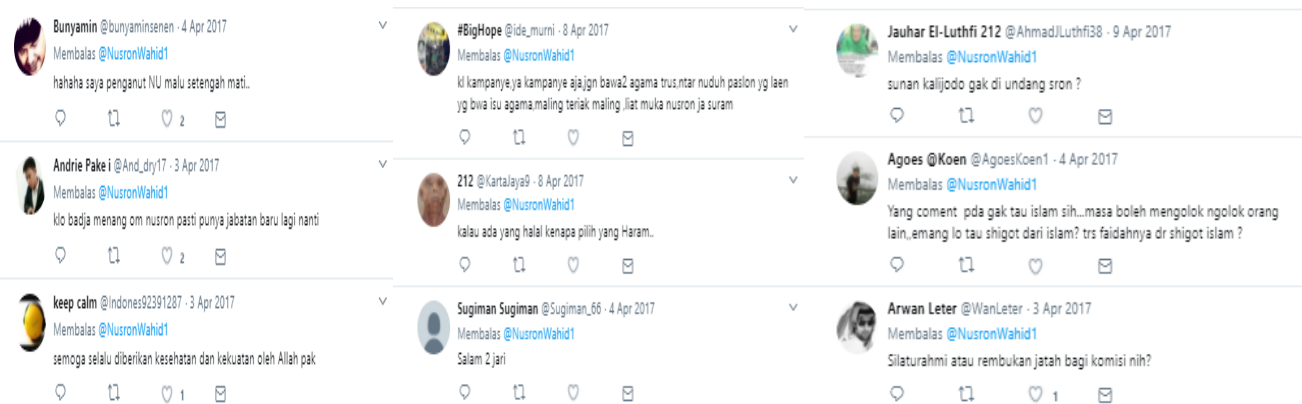

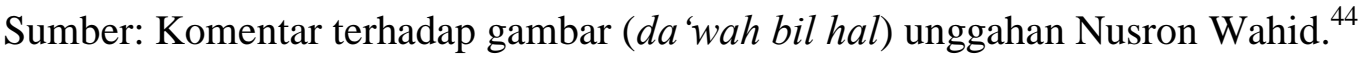

Di dalam komentar-komentar yang dilontarkan oleh para mad'u menujukkan bahwa perbedaan persepsi menjadi hal yang sering terjadi dalam menanggapi sebuah pesan dakwah yang disampaikan oleh seorang public figure, meskipun tujuannya adalah untuk menunjukkan bentuk aksi sosial yang dilakukan oleh salah seorang calon pemimpin dari kalangan umat Islam. Ada netizen yang mengomentari bahwa bahwa tidak sepantasnya bentuk kampanye politik menggunakan agama sebagai jalannya, kemudian ada yang berkomentar bahwa hal ini hanya sekedar sebuah bentuk silaturahmi, ada yang meningtkan bahwa sebaiiknya umat Islam tidak berprasangka buruk terhadap apa yang dilakukan oleh beliau, dan ada yang justru malah dengan tegas menyatakan bahwa sebagai warga NU merasa malu dengan sikap yang ditujukkan oleh organisasinya. Intinya bahwa apapun komentar tersebut adalah hak individual bagi setiap pengguna Twitter dalam menanggapi gambar tersebut.

Berdasarkan pada serangkaian contoh yang dipaparkan oleh peniliti yang mengambarkan tentang unsur-unsur dakwah dan bentuk dakwah yang terdapat di dalam media sosial Twitter sepanjang momentum Pilkada DKI Jakarta dapat disimpulkan bahwa hal tersebut menunjukkan adanya transformasi dakwah yang telah dipahami secara seksama oleh para dai dan mad'u, sehingga tidak terdapat kendala yang membatasi jalur interaksi diantara keduanya.

${ }^{44}$ Sumber Data 56: https://www.twitter.com/NusronWahidl/status/. Diakses 1 Februari 2018 pukul 17.12 


\section{DAFTAR PUSTAKA}

Amrullah Ahmad, Materi dan Metode Penyiapan Disiplin Dakwah Islam dalam Kurikulum IAIN 1995 dalam M. Tata Taufik, Dakwah Era Digital, (e-book edition; Ciawi: Pustaka Al Ikhlas, 2013)

Arnold Pacey, The Culture of Technology, Ninth Printing dalam Amar Ahmad, Dinamika Media Islami di Media Online (Jurnal Ilmu Komunikasi Vol. 11 No. 1; UIN Alauddin Makassar, 2013)

Herbert Mercuse, One Dimensional Man, terj. Silvester G. Sukur dan Yusup Priyasudiarja Manusia Satu Dimensi (Yogyakarta. Cempaka Putih. 2016)

Japaruddin, Media Massa dan Dakwah (Jurnal Dakwah Vol. XIII, No. 1; STAIN Bengkulu. 2012)

Novia Ika Setiyani, Penggunaan Media Sosial sebagai Sarana Komunikasi Komunitas (Jurnal Ilmu Komunikasi: Universitas Sebelas Maret, Surakarta. 2013), h. 2

Oliver Abou, Twitter (Paris: Micro Application. 2009)

Rogers Everette, A History of Communication Study, dalam Rulli Nasrullah, Komunikasi AntarBudaya: Di Era Budaya Siber (Cet.2; Jakarta: Pranemdia Group. 2014)

Tee Morris, All a Twitter: A Personal and Professional Guide to Social Networking with Twitter (Indiana: Pearson Education, Inc. 2010)

Tee Morris, All a Twitter: A Personal and Professional Guide to Social Networking with Twitter (Indiana: Pearson Education, Inc. 2010)

Tim O'Reilly and Sarah Milstein. The Twitter Book (California: O'Reilly Media, Inc. 2009)

Tim O'Reilly and Sarah Milstein.The Twitter Book (California: O'Reilly Media, Inc. 2009)

\section{Internet}

https://twitter.com. Diakses pada tanggal 18 Agustus 2017 pukul 20.13

https://twitter.com/aagym. Diakses pada tanggal 17 Agustus 2017 pukul 24.32

https://twitter.com/aagym/status/892530618654801920. Diakses pada tanggal 18 Agustus 2017 pukul 19.02

https://twitter.com/aagym/status/892530618654801920. Diakses pada tanggal 18 Agustus 2017 pukul 19.51

https://twitter.com/login?lang=id. Diakses pada tanggal 17 Agustus 2017 pukul 24.08

https://twitter.com/marifinilham. Diakses 07 Maret 2018 Pukul 10.11

https://twitter.com/marifinilham/followers. Diakses 07 Maret 2018 Pukul 09.09 
https://twitter.com/saiqaqil. Diakses 07 Maret 2018 Pukul 11.09

https://twitter.com/saiqaqil/followers. Diakses 07 Maret 2018 Pukul 09.15

https://twitter.com/signup?lang=id. Diakses pada tanggal 17 Agustus 2017 pukul 23.50

https://twitter.com/Tajibarani21. Diakses pada tanggal 17 Agustus 2017 pukul 24.52

https://www.twitter.com/. Diakses 21 Januari 2018 pukul 12.53

https://www.twitter.com/aagym/status/. Diakses 31 Januari 2018 pukul 20.56

https://www.twitter.com/BuyaSyaffi/status/. Diakses 05 April 2017 pukul 15.17

https://www.twitter.com/BuyaSyaffi/status/. Diakses 05 April 2017 pukul 15.17

https://www.twitter.com/gusmusgusmu/status/. Diakses 31 Januari 2018 pukul 20.56

https://www.twitter.com/NusronWahid1/status/. Diakses 01 Februari 2018 pukul 15.22

https://www.twitter.com/NusronWahid1/status/. Diakses 1 Februari 2018 pukul 16.47

https://www.twitter.com/NusronWahid1/status/. Diakses 1 Februari 2018 pukul 16.47

https://www.twitter.com/NusronWahid1/status/. Diakses 1 Februari 2018 pukul 17.12

https://www.twitter.com/Prof_Azyumardi/status/. Diakses 5 April 2017 pukul 12.57

https://www.twitter.com/Prof_Azyumardi/status/. Diakses 5 April 2017 pukul 13.05

https://www.twitter.com/RizieqSyihabFPI/status/. Diakses 1 Februari 2018 pukul 16.47

https://www.twitter.com/RizieqSyihabFPI/status/. Diakses 1 Februari 2018 pukul 17.01

https://www.twitter.com/RizieqSyihabFPI/status/. Diakses 1 Februari 2018 pukul 17.01

https://www.twitter.com/RizieqSyihabFPI/status/. Diakses 7 Februari 2018 pukul 17.21

https://www.twitter.com/RizieqSyihabFPI/status/. Diakses 7 Februari 2018 pukul 17.21

https://www.twitter.com/sahal_AS/status/. Diakses 17 Februari 2017 pukul 13.48

https://www.twitter.com/sahal_AS/status/. Diakses 17 Februari 2017 pukul 13.51

https://www.twitter.com/saidaqil/status/. Diakses 1 Februari 2018 pukul 14.47

https://www.twitter.com/saidaqil/status/. Diakses 1 Februari 2018 pukul 14.51

https://www.twitter.com/ulil/status/. Diakses 5 April 2017 pukul 13.49

https://www.twitter.com/ulil/status/. Diakses 5 April 2017 pukul 13.55 